\title{
Sól og sandur: Ferðir Íslendinga til Kanaríeyja
}

\author{
Kristín Loftsdóttir, Auður Arna Arnardóttir, Már Wolfgang Mixa og \\ Guðbjört Guðjónsdóttir ${ }^{1}$
}

\begin{abstract}
Ágrip
Rannsóknir á ferðamennsku til Íslands hafa verið í uppgangi síðastliðin ár, en verulega skortir á rannsóknir á utanlandsferðum Íslendinga. Hvort tveggja er pó hluti af peim hnattræna veruleika sem Ísland er hluti af og vettvangur margvíslegra efnahagslegra gjörninga. Greinin fjallar um ferðir Íslendinga til Kanaríeyja og spyr hvað einkennir ferðir Íslendinga til Kanaríeyja síðasta áratuginn og hverskonar áfangastaður Kanaríeyjar er fyrir Íslendinga. Greiningin styðst við megindleg gögn, p.e. niðurstöður spurningakönnunnar og greiningu á fyrirliggjandi gögnum frá Hagstofu Kanaríeyja og Ferðamálastofu Íslands.

Rannsóknir erlendis endurspegla að spænsk yfirvöld hafa reynt að leggja áherslu á að Kanaríeyjar hafi upp á meira að bjóða en eingöngu sólarlandaferðir. Jafnframt sýna erlendar rannsóknir að mörk milli peirra sem eru ferðamenn, aðfluttir, eða sem vinna á eyjunum eru oft óljós og flæðandi. Greining megindlegra gagna fyrir greinina sýnir að Kanaríeyjar hafa haft vaxandi mikilvægi sem áfangastaður fyrir ferðalanga frá Íslandi síðasta áratug og pá sérstaklega eyjan Tenerife. Aðdráttarafl Kanaríeyja sem áfangastaðar virðist út frá niðurstöðum könnunarinnar fyrst og fremst vera í tengslum við veðurfar eyjanna og afpreyingu, en bent er jafnframt á að rétt eins og annarstaðar getur hreyfanleiki til eyjanna falið í sér flæðandi hópa par sem mörk ferðamanna, aðfluttra, eða vinnandi eru ekki alltaf skýr.
\end{abstract}

\section{Abstract}

Research on tourism in Iceland has gained increased salience, while there is a considerable lack of research on tourism from Iceland. Mobilities to and from Iceland are both a part of a global reality that Iceland is a part of and sites for different economic activities. This article focuses on Icelandic mobilities to the Canary Islands, based on the work of scholars focusing on the creation of destinations. The research draws out the main characteristics of Icelandic travels to the Canary Islands during the past decade. It further shows what kind of destination the Canary Islands are for people from Iceland. The analysis is quantitative, using a questionnaire and analysis of data from the Canary Islands Social Statistics and the Icelandic Tourism Board. Other research reflects that destination branding of the Canary Islands has

1 Kristín Loftsdóttir er prófessor í mannfræði við Háskóla Íslands. Netfang: kristinl@hi.is. Auður Arna Arnardóttir er dósent í viðskiptafræði við Háskólann í Reykjavík. Netfang: auduraa@ru.is. Már Wolfgang Mixa er lektor í viðskiptafræði við Háskólann í Reykjavík. Netfang: marmixa@ru.is. Guðbjört Guðjónsdóttir er verkefnisstjóri hjá Félagsvísindastofnun Háskóla Íslands. Netfang: gudbjort@hi.is. Pessi grein er skrifuð sem hluti af Rannsóknarverkefninu CERM (Creating Europe through Racialized Mobilitites). Verkefnið er styrkt af Rannsóknasjóði (nr. 207062-051) og Rannsóknarsjóð Háskóla Íslands.

This work is licensed under a Creative Commons Attribution 4.0 License.

DOI: https://doi.org/10.24122/tve.a.2021.18.1.3 
attempted to present the islands as more than a beach vacation spot as well as demonstrating that different categories of travellers are often quite unclear and fluid. The analysis of quantitative data shows that travel abroad has increased from Iceland. The Canary Islands have grown in significance as a destination for people from Iceland for the last decade, especially the island Tenerife. As a destination, the Canary Islands' primary attraction seems to be the mild climate and activities associated with the sun and the beach. The boundaries between tourists and other groups, such as residents, immigrants, and those working there, are often unclear.

JEL flokkun: L83, M37, R41, Z32, Z33

Lykilorð: Sólarlandaferðir; áfangastaður; Kanaríeyjar; hreyfanleiki.

Keywords: Sun and Sand tourism; destination; Canary Islands; mobility.

\section{Sun and Sand: Icelandic Travels to the Canary Islands}

\section{Inngangur}

Norðurlandabúar hafa lengi verið mikilvægur markhópur fyrir Kanaríeyjar hvað varðar fjöldaferðamennsku (Barros, 2014) og eru Íslendingar par engin undantekning. Samkvæmt Hagstofu Kanaríeyja voru alls 49.216 komur frá Íslandi árið 2019 (ISTAC, e.d.), sem pýðir að 14\% landsmanna (Hagstofa Íslands, e.d.a) hafi ferðast til Kanarí pað árið ef gert er ráð fyrir að hver fari eingöngu í eina ferð árlega. Samtals eyddu Íslendingar erlendis alls 191 milljarði króna með notkun debit- og kreditkorta árið 2019, en sú upphæð nam um 6,3\% af vergri landsframleiðslu Íslands (Seðlabankinn, e.d., Hagstofa Íslands, e.d.b).

Pessi grein fjallar um ferðir Íslendinga til Kanaríeyja og beinir sjónum sérstaklega að síðastliðnum 10 árum. Hún undirstrikar að ferðamál eru ekki bundin eingöngu við komur ferðalanga til landsins heldur hafa einnig að gera með hreyfanleika frá Íslandi. Lögð er áhersla á umfang og einkenni Íslendinga sem ferðalanga til Kanarí, p.e. hverjir fara til Kanarí og í hvaða tilgangi. Rannsóknarspurningin er í stuttu máli: Hvað einkennir ferðir Íslendinga til Kanaríeyja sídasta áratuginn og hverskonar áfangastaður eru Kanaríeyjar fyrir Íslendinga? Til pess að leggja drög að svörun slíkrar spurninga kortleggur greinin fjölda peirra sem fara til Kanaríeyja, meginástæður pess að för sé heitið til eyjanna og hverju fólk leitast eftir á eyjunum. Líta má á greinina sem fyrstu skref í að kortleggja einkenni og umfang ferða Íslendinga til Kanarí og hverslags áfangastaður Kanarí er fyrir Íslendinga.

Viðfangsefni rannsókna á Íslandi sem snúa að ferðamálum hafa á undanförnum árum einkum snúið að ferðalögum til Îslands (til dæmis Gunnar Pór Jóhannesson, 2012; Gunnar Pór Jóhannesson og Huijbens, 2013). Ein meginástæða pess að slíkar rannsóknir hafa verið mikilvægar má rekja til snöggra breytinga á stöðu Íslands sem áfangastaðar, en landið hefur á stuttum tíma færst frá pví að vera jaðaráfangastaður ferðafólks yfir í svæði fjöldaferðamennsku (Katrín Anna Lund, Kristín Loftsdóttir og Leonard, 2017). Rannsóknir á ástæðum utanlandsferða frá Íslandi eru hins vegar mun fátíðari. Ferðalög frá Íslandi jukust pó verulega á öðrum áratug pessarar aldar eftir að hafa dregist nokkuð saman fyrstu árin eftir efnahagshrunið 2008. Árið 2019 voru t.d. 80\% Íslendinga sem ferðuðust til útlanda og meðalfjöldi utanlandsferða peirra var 2,6 ferðir á ári (Birkir Örn Gretarsson o.fl., 2020). Samkvæmt upplýsingum frá Ferðamálastofu höfðu 41\% svarenda í peirri könnun hjá peim, sem höfðu ferðast, farið til Spánar eða Portúgal (Birkir Örn Gretarsson o.fl., 2020), en frá 2012 hefur pessi flokkur (Spánn/Portúgal) verið í premur efstu sætunum yfir vinsælustu áfangastaði Îslendinga og raunar sá vinsælasti árin 2014-2019, að árinu 2017 undanskildu pegar pað var næst vinsælasti áfangastaðurinn á eftir Bretlandi/Írlandi (Birkir Örn Gretarsson o.fl., 2020). ${ }^{1}$

Greiningin hér byggir fyrst og fremst á megindlegum gögnum: Annarsvegar niðurstöðum spurningakönnunnar og hinsvegar greiningu fyrirliggjandi gagna Hagstofu Kan- 
aríeyja á Spáni og upplýsingum frá Ferðamálastofu Íslands, hér eftir nefnd Ferðamálastofa. Spurningakönnunin var lögð fyrir netpanel Félagsvísindastofnunar í mars 2019. Pá er leitast við að svara hvað megi lesa úr spurningakönnuninni um hvernig íslenskir ferðalangar upplifa eyjarnar sem áfangastað. Ferðalög til Kanaríeyja eru einnig stuttlega sett í víðara sögulegt samhengi.

Greinin er hluti af stærra rannsóknarverkefni um pverpjóðleg tengsl Kanaríeyja og Íslands í gegnum tíðina. Verkefnið í heild skoðar, með megindlegum og eigindlegum aðferðum, upplifun Íslendinga af Kanaríeyjum sem áfangastað og reynslu fólks sem vinnur par í ferðapjónustu. Verkefnið ber einnig saman Kanarí og Ísland sem áfangastað, en Ísland rétt eins og Kanarí hefur í auknum mæli orðið vettvangur fjöldaferðamennsku. Pessi grein afmarkast við ferðir Íslendinga til Kanaríeyja síðastliðin 10 ár og pað sem einkennir pann hóp sem ferðast hefur til eyjanna á pessu tímabili. Ástæða pess að pessi tímarammi er notaður er að Kanaríeyjar sem áfangastaður hefur orðið mun vinsælli á síðastliðnum áratug. Eins og sýnt verður fram á í pessari grein hófst pessi próun skömmu fyrir hrun, pað dró úr henni í framhaldi af hruninu en hún náði sér pó fljótt aftur á strik. Miklar breytingar hafa augljóslega átt sér stað á árinu 2020 og 2021 í samhengi við Covid heimsfaraldurinn en vænta má að ferðir til Kanaríeyja muni aftur fara vaxandi með fjölgun bólusettra einstaklinga.

Eftir stutta umfjöllun greinarinnar hvað varðar kenningalega nálgun sem liggur til grundvallar, setur priðji kafli hennar pessi ferðalög í stutt sögulegt samhengi og segir frá upphafi Kanaríferða á sjöunda áratugnum. Í fjórða kafla er gerð grein fyrir umfangi utanlandsferða Íslendinga til Spánar og Kanaríeyja síðastliðin 10 ár út frá fyrirliggjandi gögnum frá Hagstofu Kanaríeyja og Ferðamálastofu Íslands. Fimmti kafli greinarinnar fjallar um niðurstöður úr spurningavagni Félagsvísindastofnunar sem snúa að helstu einkennum ferðalaga til Kanaríeyja síðastliðin 10 ár. Að lokum eru helstu niðurstöður greiningarinnar dregnar saman. Einnig er par gerð grein fyrir peim spurningum sem vakna við ritun greinarinnar og framtíðarviðfangsefnum.

\section{Fræðilegur bakgrunnur}

\subsection{Hreyfanleiki og ferðafólk}

Til pess að staðsetja í víðara samhengi ástæður pess að Íslendingar velja sér Kanarí sem áfangastað er mikilvægt að skoða stuttlega kenningar um sköpun áfangastaða og fræðilega umræðu hvað varðar Spán sem áfangastað. Fræðifólk á sviði ferðamálafræða hefur lagt áherslu á sköpun áfangastaða sem miðlæga í rannsóknum á ferðamennsku, par sem samspil ólíkra pátta veitir stöðum aðdráttarafl (Eyrún Jenný Bjarnadóttir, 2010; Saarinen, 2004). Aukinn hreyfanleiki fólks á milli staða, hefur verið hluti af hnattvæddum ferlum síðustu tvo áratugi en lengi vel talaði fræðifólk um aukna einsleitni sem einn fylgifisk hnattvæðingarinnar (Inda og Rosaldo, 2008). Aukinn hreyfanleiki fólks og fjármagns hefur m.a. að einhverju leyti falið í sér aukna einsleitni í mótun ákveðinna áfangastaða, par sem oft er verið að svara áætluðum pörfum neytenda (Saarinen, 2004), jafnframt pví að markaðssetning áfangastaða getur mótast af staðalmyndum um íbúa eða landið sjálft (Kristín Loftsdóttir, 2015). Edward Huijbens og Gunnar Pór Jóhannesson (2019) benda pó á mikilvægi pess að skoða skörun ólíkra markmiða í sköpun áfangastaða sem eru ekki eingöngu efnahagsleg, heldur geta samhliða verið menningarleg eða mótast af svæðisbundnum hagsmunum jaðarsvæða. Í pessu samhengi má benda á að innan umræðu um fjölbreytileika og hnattvæðingu undirstrikuðu mannfræðingar mikilvægi pess að skoða atbeini ólíkra gerenda í að móta og endurvinna hnattræn fyrirbæri (Inda og Rosaldo, 2008). Pannig hefur til dæmis Vainikka (2013) bent á að ekki megi gefa sér fyrirfram að upplifun og ástæður allra sem taka pátt í fjöldaferðamennsku séu pær sömu en aðrir hafa jafnframt lagt áherslu á mikilvægi pess að skoða hvernig ferðalangar stíga oft út fyrir pað sem peir sem markaðssetja áfangastaðina gera ráð fyrir (sjá til dæmis Larsen og Urry, 2011). 
Spánn varð áfangastaður fjöldaferðmennsku á sjöunda áratug síðustu aldar með komu ferðafólks frá Pýskalandi og Bretlandi og í kjölfarið frá Norðurlöndunum (Gustafson 2002:902). Spænsk stjórnvöld sáu pá pegar mikilvægi ferðapjónustu fyrir hagvöxt og hagpróun og rík áhersla var lögð á að fá sem flesta ferðmenn til landsins (Almeida 2013:11). Meginpungi stjórnvalda á sköpun Spánar sem áfangastaðar lá í áherslu á sól og strönd en eftir 1990 hefur verið reynt að leggja ríkari áherslu á fleiri pætti svo sem menningu Spánar og náttúru í víðari skilningi (Andreu o.fl., 2000). Einnig hefur verið lögð áhersla á að dreifa ferðalöngum betur um landið og skapa fjölbreyttari atvinnutækifæri fyrir heimamenn en „,sól og strönd“ býður upp á (Scherrer o.fl, 2009). Á seinasta tug síðustu aldar minnkaði vægi fjöldaferðamennsku almennt, par sem einstaklingar skipuleggja ferðir sínar sjálfir í auknum mæli og velja fjölbreyttari áfangastaði (O’Reilly 2017).

Rannsóknir erlendis hafa bent á að skil á milli peirra sem fara til Spánar til að búa og/ eða vinna hluta úr árinu og peirra sem fara sem ferðamenn geta verið óljósar ( $\mathrm{O}^{\prime}$ Reilly 2017). Norðurlandabúar dvelja, til dæmis, oft hluta ársins á Spáni en sækja ekki um íbúaleyfi (e. residence permit), sem pýðir að peir koma ekki fram í opinberri tölfræði sem íbúar (Gustafson 2002:903; Haug et al., 2007). Fljótlega eftir upphaf ferðamennskunnar á Spáni hófust kaup Norður-Evrópubúa á eignum á svæðinu, sem var einfaldara sökum aukinnar hagsældar í heimalöndum peirra samhliða hækkandi húsnæðisverði (Olson og O’Reilly, 2007, sjá einnig Haug o.fl., 2007). Margir úr pessum hópi kynnast Spáni sem ferðamenn og kjósa svo að vera lengur pegar peir fara á eftirlaun (O’Reilly 2017, 141). Einnig hefur verið bent á að vegna pess að mörk á milli vinnu og ferðalaga geti verið óljós er ekki alltaf gagnlegt að draga upp sterkar afmarkanir á milli peirra sem eru ferðmenn og peirra sem vinna tímabundið á ferðamannastöðum (Cohen and Tulemark, 2013). Í sumum tilfellum hefur fyrri reynsla sem ferðamaður jafnframt áhrif á að einstaklingar ákveða að eyða efri árum eða eftirlaunum á suðrænni slóðum (Rodriguez, 2001), sem einnig gerir mörkin milli aðfluttra og ferðamanna flæðandi.

Eins og fyrri umræða endurspeglar eru ferðalög ein tegund hreyfanleika sem felur ekki eingöngu í sér hreyfingu fólks á milli staða heldur einnig fjármagns. Petta hefur undanfarið komið fram í íslensku efnahagslífi í kjölfar Covid pegar Íslendingar hættu tímabundið að ferðast erlendis og fjármagn, sem áður var eytt erlendis, safnaðist innanlands. Ferðalög erlendis tengjast atbeini Íslendinga sem efnahagslegir gerendur á margvíslegan hátt, t.d. sem kaupendur á erlendum gjaldeyri og vali á pví í hvað honum er eytt. Slík ferðalög skapa einnig atvinnu á Íslandi, svo sem í rekstri og starfsemi íslenskra ferðaskrifstofa sem fela í sér margvísleg pverpjóðleg umsvif. Rannsóknir erlendis hafa einnig sýnt að ferðamennska utan eigin landa leiðir oft til annarra tengsla við efnahagslegar athafnir, svo sem kaupa á eignum eða til fyrirtækjareksturs (Cohen o.fl., 2013; Rodriguez, 2001). Húsnæði erlendis getur pá verið annað heimili eða til útleigu (Perles-Ribes o.fl., 2018). Vegna pess að ferðamenn frá Norður- til Suður-Evrópu eru flæðandi hópur er erfitt að afmarka hvort viðkomandi er árstíðarbundinn íbúi eða ferðamaður, og jafnvel hvort hann fær tekjur heimafyrir vegna útleigu íbúða eða vinnur jafnvel að hluta til í landinu (O’Reilly, 2007).

\subsection{Upphaf ferða Íslendinga til Kanaríeyja}

Kanaríeyjar er nafn á eyjaklasa rétt fyrir utan vesturströnd Norður-Afríku, nánar tiltekið Vestur-Sahara og Marokkó. Eyjarnar sjö sem mynda eyjaklasann eru sjálfstjórnarsvæði innan Spánar. Pekktustu eyjarnar með mestu byggðina eru Tenerife og Gran Canaria, sem einblínt er á í pessari grein. Sköpun Kanarí sem áfangstaðar fjöldaferðamennsku átti sér stað upp úr 1960 með góðum flugsamgöngum við aðra hluta Evrópu (sjá t.d. Barros, 2014). Árin á undan hafði einræðisherrann Franco lagt grunn að auknum ferðalögum til eyjanna par sem liðkað hafði verið fyrir erlendum fjárfestingum og ráðstafanir gerðar til að minnka verðbólgu á Spáni. Einnig var slakað á kröfum varðandi vegabréfsáritanir og gengi gjaldmiðilsins peseta fellt. Norðurlöndin urðu strax mikilvæg í pessu tilliti fyrir Kanaríeyjar, m.a. í fjárfestingum (Domínguez-Mujica o.fl., 2011). Fyrsta leiguflugið til Kanarí (e. tourism 
charter flight) var skipulagt af sænskri ferðaskrifstofu til Gran Canaria um jólin 1957. Ári seinna var flogið til Gran Canaria daglega (Barros, 2014, bls. 4). Norðurlöndin, og pá sérstaklega Svípjóð og Noregur, urðu priðji stærsti markaður Kanaríeyja. Barros bendir á að 1,5 milljón Norðurlandabúa heimsækja eyjarnar árlega, sem eru um $6 \%$ af fólki í pessum löndum (2014, bls. 4).

Á Íslandi hófust ferðir til Kanaríeyja snemma pegar litið er til reglulegra utanlandsferða Íslendinga og líta má á ferðir til Spánar sem samofnar sögu fjöldaferðamennsku frá Íslandi. Árið 1936 voru sett fyrstu lögin um íslensk ferðamál og samhliða var Ferðaskrifstofa ríkisins stofnuð. Hún hafði einkarétt á almennri ferðaskrifstofustarfsemi allt til ársins 1964 pegar ný lög voru sett um ferðamál (Samgönguráðuneytið, 1983, bls. 10). Pegar Ferðaskrifstofa ríkisins skipulagði, árið 1952, 19 daga siglingu til Spánar, seldist hún upp á fáeinum dögum (sjá einnig umræðu í Erla Erlendsdóttir og Karl Jóhannsson, 2020). Fleiri ferðir til Spánar komu í kjölfarið sem mikið var fjallað um í dagblöðum á peim tíma. Spánverjar höfðu flutt inn mikið magn af íslenskum saltfiski og íslensk stjórnvöld voru í vandræðum með að ráðstafa inneign sem peir áttu á Spáni. Petta hafði mögulega áhrif á hversu greiðlega gekk að fá gjaldeyri fyrir ferðina, en stjórnvöld voru venjulega frekar óviljug til að veita leyfi fyrir kaupum á gjaldeyri vegna gjaldeyrisskorts í landinu á pessum tíma (Stefán Svavarsson, 2017, bls. 77). Fyrsta almenna ferðaskrifstofan, Orlof, var svo stofnuð um miðjan 6. áratuginn og bauð meðal annars upp á ferðir til Spánar. Undir lok sjötta áratugarins fóru Ingólfur Guðbrandsson og Guðni Pórðarson að selja ferðir til Spánar. Árið 1959 var felld niður krafan um vegabréfsáritun Íslendinga til landsins sem einfaldaði mjög ferðalög pangað (Stefán Svavarsson, 2017, bls. 77-78). Lengi vel vantaði mjög áreiðanlegar tölfræðilegar upplýsingar um bæði ferðir innanlands og erlendis, enda er sagt með skýrum orðum í skýrslu um ferðamál á Íslandi frá 1983 að engar upplýsingar séu til um ferðavenjur Íslendinga erlendis (Samgönguráðuneytið, 1983, bls. 1, 4).

Fyrstu skipulögðu ferðirnar til Kanaríeyja frá Íslandi hófust um miðjan sjöunda áratuginn. Skipið Gullfoss, sem var í eigu Eimskipafélagsins, hóf siglingar til Kanarí árið 1966, en flogið var hluta af leiðinni til að stytta ferðatímann. Í ferðinni var stoppað hvort tveggja á eyjununum Gran Canaria og Tenerife, sem urðu mikilvægir áfangastaðir Íslendinga (Porsteinn Jónatansson, 1966). Ferðaskrifstofurnar Sunna og Útsýn buðu upp á ferðir til Kanaríeyja snemma á sjöunda áratugnum. Guðni Pórðarson, stofnandi ferðaskrifstofunnar Sunnu, telur í viðtali sem tekið var 1980, að hann hafi staðið fyrir fyrsta íslenska leigufluginu til Tenerife árið 1962 (Guðlaugur Bergmundsson, 1980). Samkvæmt viðtali við fulltrúa Útsýnar hóf pó Útsýn leiguflug til sólarlanda árið 1958 og ýmist til Costa del Sol eða Kanaríeyja. Farið var um páska og beið flugvélin eftir farpegunum (Guðlaugur Bergmundsson, 1980). Árið 1969 hóf Flugfélag Íslands ferðir til Kanaríeyja eins og sjá má í auglýsingum í dagblöðum frá peim tíma (Nýr áfangi á Kanarí blómaeyjan Tenerife, 1975, bls. 1). Auglýsing Flugfélags Íslands og Loftleiða í Morgunblaðinu frá 1974 endurspeglar að ferðir til Kanaríeyja höfðu fest sig í sessi pegar bent er á að á ensku ströndinni sé búið að opna skrifstofu til að pjónusta farpega og aðstoða við skipulagningu styttri ferða „um og út fyrir eyjuna“ (Úr vetrarríki í sólarfrí í skammdeginu, 1974, bls. 37). Af pessu er ljóst að á sjöunda áratugnum vaknaði mikill áhugi á slíkum ferðum í takt við áherslur á öðrum Norðurlöndum.

Í næsta kafla er nánar fjallað um umfang ferða til Kanaríeyja 2012 til 2019, en benda má á að rétt eins og annarstaðar í Norður-Evrópu fer fólk frá Íslandi ekki eingöngu til Kanarí sem ferðafólk. Til dæmis fara sumir til að vinna í lengri eða styttri tíma og aðrir eru aðfluttir. Margvísleg pjónusta hefur m.a. skapast á Kanarí í kringum ferðalög Íslendinga pangað. Íslendingar vinna sem fararstjórar á vegum íslenskra ferðaskrifstofa eða í ferðapjónustu á eigin vegum (sjá til dæmis Svali lifði, 2019) og einnig eiga nokkrir Íslendingar sem búa á eyjunum veitingarekstur. Má par sérstaklega nefna svokallaðan „Klörubar" (nafn hans er Cosmos) á Gran Canaria og Nostalgia á Tenerife. Bæði veitingahúsin eru á pekktustu fjöldaferðamennskustöðum eyjanna, amerísku ströndinni á Tenerife og ensku 
ströndinni á Gran Canaria, og hafa verið mikilvæg til að halda utan um og jafnvel stuðla að myndun Íslendinga-samfélaga á pessum stöðum með pví að standa fyrir margskonar viðburðum sem höfða sérstaklega til Íslendinga. Pví til viðbótar selja Íslendingar og eiga eignir á Spáni sem peir leigja út í sumum tilfellum (sjá viðtal Spánarheimili, 2021), og er ólíklegt að Kanaríeyjar séu undantekning frá pví. Hér sjáum við, rétt eins og fræðifólk hefur bent á annarstaðar, hvernig ólíkar tegundir hreyfanleika falla saman, p.e. ferðlög til eyjanna verða í sumum tilfellum að viðskiptatækifærum (eigendur Nostalgiu komu t.d. upphaflega sem ferðamenn til eyjanna (Fluttu til Eyjanna, 2016)).

Að auki hafa Íslendingar búið á Kanaríeyjum í tengslum við veiðar íslenskra útgerðarfélaga úti fyrir ströndum Vestur-Afríku (Hjörtur Gíslason, 2007) sem endurspeglar hvernig óskyldir efnahagslegir pættir geta einnig haft áhrif á hreyfanleika til eyjanna. Erfitt er að meta hversu margir Íslendingar búa á eyjunum á hverjum tíma vegna pess að fólk tilkynnir ekki nauðsynlega búsetu til spænskra yfirvalda, en einnig vegna pess hversu flæðandi slíkir flokkar eru eins og fyrr var sagt. Áætlað var pó árið 2018 að 1.000 Íslendingar byggju á Kanaríeyjum (Erla Erlendsdóttir og Karl Jóhannsson, 2020).

\section{Gögn um ferðir Íslendinga til Kanaríeyja}

Ferðamálastofa Íslands hefur safnað gögnum um ferðir Íslendinga erlendis frá árinu 2012. Par má sjá að árin 2009-2014 fóru innan við 70\% Íslendinga til útlanda (innan við 50\% árið 2009) en árin 2015-2019 var pað hlutfall yfir 70\% og yfir 80\% árin 2018 og 2019. Einnig kemur fram að árin 2012-2015 var farið að meðaltali 2,2 til 2,4 ferðir á ári en árin 2016-2019 var um að ræða 2,5 til 2,8 ferðir (Birkir Örn Gretarsson o.fl., 2020, bls. 22). Ef við skoðum ferðir til Spánar eða Kanarí út frá pessum gögnum pá greina gögn Ferðamálastofu pví miður ekki á milli ferða til Spánar og Portúgals, og eru Madeira og Kanarí jafnframt hluti af sömu gögnum. Ekki er pannig aðgreint á milli landanna né hvort um sé að ræða sólarlandaferðir, borgarferðir eða ferðir milli landa í öðrum tilgangi. Mynd 1 sýnir að af peim einstaklingum sem á annað borð fóru til útlanda hvert ár, jókst hlutfall peirra sem fóru til Spánar/Portúgals stöðugt árin 2012 til 2019 (Birkir Örn Gretarsson o.fl., 2020, bls. 26). Árið 2012 voru 23\% af ferðum erlendis til Spánar/Portúgal en rúmlega 40\% árin 2018 og 2019. Benda má á að árið 2012 var Ísland smám saman að rétta úr kútnum eftir hrunið árið 2008 og utanlandsferðir sem flokka megi sem skemmtiferðir jukust í takti við betri efnahag eftir pví sem leið á áratuginn.

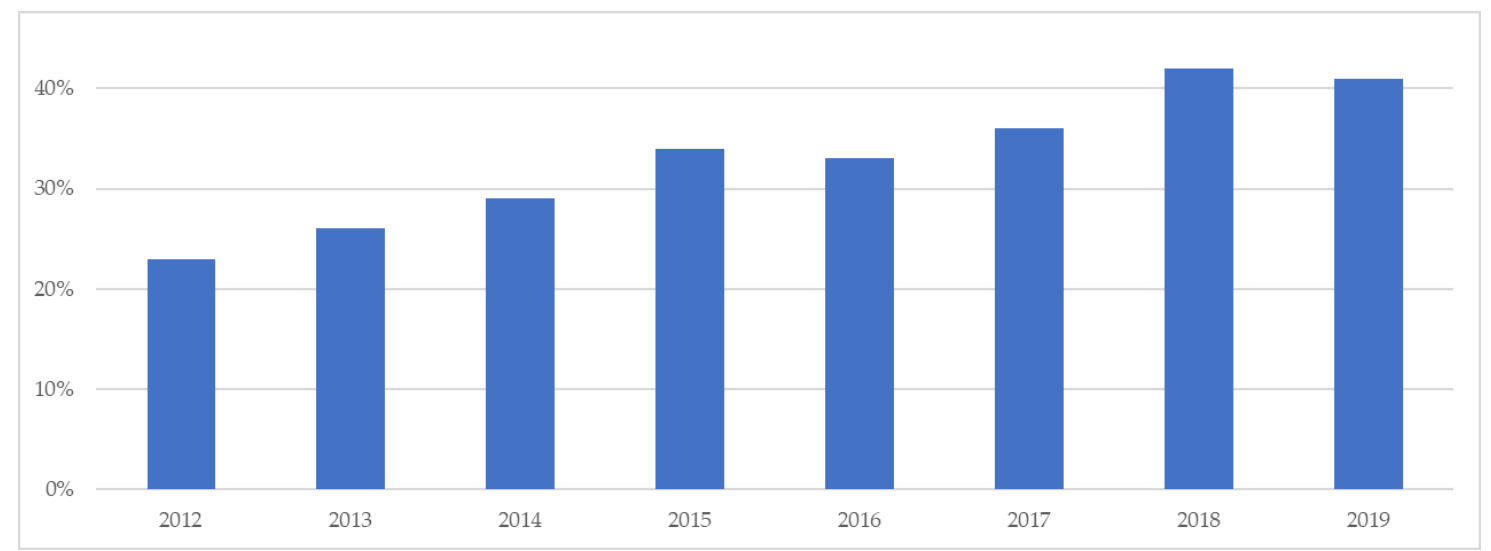

Mynd 1. Hlutfall ferða til Spánar/Portúgals af heildarfjölda ferðalaga Íslendinga erlendis (Heimild: Ferðamálastofa, 2020)

Til að fá tilfinningu fyrir fjölda Íslendinga í stað hlutfalls peirra sem ferðuðust til Spánar/ Portúgals á pessu tímabili er hægt að styðjast við tölur í töflu 1 að neðan. Í fyrsta dálki sést hlutfall Íslendinga sem ferðast til útlanda á hverju ári. Næsti dálkur sýnir hlutfall peirra 
sem fóru til Spánar eða Portúgals af peim sem á annað borð fóru erlendis. Priðji dálkurinn er margföldun á hlutföllum í fyrsta og öðrum dálki, sem sýnir pá hlutfall peirra sem ferðuðust til Spánar eða Portúgals ár hvert af heildarfjölda Íslendinga. Fjórði dálkurinn sýnir mannfjölda Íslendinga í upphafi hvers árs og út frá pví er í fimmta dálki áætlaður fjöldi Íslendinga sem fóru til Spánar eða Portúgals fyrir hvert ár.

Með pví að miða við hlutfall fólks sem fór til útlanda og af pví pýði prósentuna sem fór til Spánar eða Portúgals (Birkir Örn Gretarsson o.fl., 2020) sést að hlutfall Íslendinga sem fór til Spánar eða Portúgals ár hvert fór úr 15\% árið 2012 í yfir 33\% árið 2019, eða rúmlega tvöfalt hærra hlutfall landsmanna. Ef sú prósenta er borin saman við mannfjölda í upphafi hvers árs (Hagstofa Íslands, e.d.a) má áætla fjölda Íslendinga sem fór til pessara landa árin 2012-2019. Par sem fjöldi Î́slendinga jókst um rúmlega 10\% á pessu tímabili pá má áætla að árlegur fjöldi Íslendinga sem fór til pessara landa hafi aukist um tæplega 150\% frá árinu 2012 til 2019.

Tafla 1. Áætluð prósenta og fjöldi Íslendinga sem ferðaðist til Spánar eða Portúgals (Byggt á heimild: Birkir Örn Gretarsson o.fl., 2020)

\begin{tabular}{|c|c|c|c|c|c|c|}
\hline Ár & $\begin{array}{l}\text { Hlutfall } \\
\text { Íslendinga } \\
\text { sem } \\
\text { ferðast }\end{array}$ & $\begin{array}{c}\text { Hlutfall til } \\
\text { Spánar/Portugals } \\
\text { af peim sem } \\
\text { ferðuðust }\end{array}$ & $\begin{array}{c}\text { Áætluð \% til } \\
\text { Spánar/Portúgals } \\
\text { af heildarfjölda } \\
\text { Íslendinga }\end{array}$ & $\begin{array}{c}\text { Mannfjöldi } \\
\text { 1.jan ár } \\
\text { hvert }\end{array}$ & $\begin{array}{c}\text { Fjöldi til } \\
\text { Spánar/Portúgals }\end{array}$ & $\begin{array}{l}\text { \# hækkun } \\
\text { milli ára }\end{array}$ \\
\hline 2012 & $64 \%$ & $23 \%$ & $15 \%$ & 319.575 & 47.041 & \\
\hline 2013 & $62 \%$ & $26 \%$ & $16 \%$ & 321.857 & 51.883 & +4.842 \\
\hline 2014 & $67 \%$ & $29 \%$ & $19 \%$ & 325.671 & 63.278 & +11.395 \\
\hline 2015 & $71 \%$ & $34 \%$ & $24 \%$ & 329.100 & 79.445 & +16.167 \\
\hline 2016 & $77 \%$ & $33 \%$ & $25 \%$ & 332.529 & 84.496 & +5.051 \\
\hline 2017 & $78 \%$ & $36 \%$ & $28 \%$ & 338.349 & 95.008 & +10.512 \\
\hline 2018 & $83 \%$ & $42 \%$ & $35 \%$ & 348.450 & 121.470 & +26.462 \\
\hline 2019 & $80 \%$ & $41 \%$ & $33 \%$ & 356.991 & 117.093 & -4.377 \\
\hline
\end{tabular}

Pessar tölur gefa vísbendingar um heildarmyndina varðandi ferðalög Íslendinga til pessara landa. Til pess að fá nánari sýn á ferðir til Kanarí sérstaklega er nauðsynlegt að styðjast við aðrar tölfræðiupplýsingar. Við einblínum pví hér eftir á gögn frá Hagstofu Kanaríeyja. Árin 1999-2004 (tölurnar ná ekki lengra aftur) fóru árlega um 7-12 púsund Íslendingar til Gran Canaria en gögnin sýna ekki flug til Tenerife á sama tíma. Árið 2005 má sjá í pessum gögnum lítinn hóp sem fer til Tenerife en hann stækkaði árið 2006 og var pá svipað stór og sá sem fór til Gran Canaria sama ár. Samtalan var komin upp í 30 púsund farpega árið 2008 en íslenska efnahagshrunið hafði töluverð áhrif á ferðir Íslendinga til eyjanna í framhaldinu og fór niður í 12 púsund farpega árið 2009. Árin eftir hrun hélst sú tala tiltölulega stöðug en ferðir til eyjanna tóku stökk árið 2014 pegar farpegafjöldinn fór úr rúmlega 16.500 yfir í 25.400. Fram til ársins 2020 var mikil aukning og árið 2019 ferðuðust tæplega 50 púsund farpegar frá Íslandi til Kanaríeyja. Benda má á að inni í peirri tölu eru einstaklingar sem ferðuðust oftar en einu sinni á ári (ISTAC, e.d.).

Tenerife hefur haldið áfram að vera vinsæll áfangastaður og hafa vinsældir staðarins samanborið við Gran Canaria verið hægt og bítandi að aukast. Öfugt við pað sem átti sér stað fyrir hrun pá er langmestur fjöldi Islendinga að fara til Tenerife. Fram að árinu 2015 fóru $65-70 \%$ ferðalanga til Tenerife en eftir pað var hlutfallið 70-80\%. Pví er magnaukning og hlutfallsleg aukning að eiga sér stað í komum til Tenerife. Voru t.d. næstum fjórfalt fleiri Íslendingar sem fóru til Tenerife árið 2018 heldur en til Gran Canaria sama ár (ISTAC, e.d.) (sjá mynd 2). 


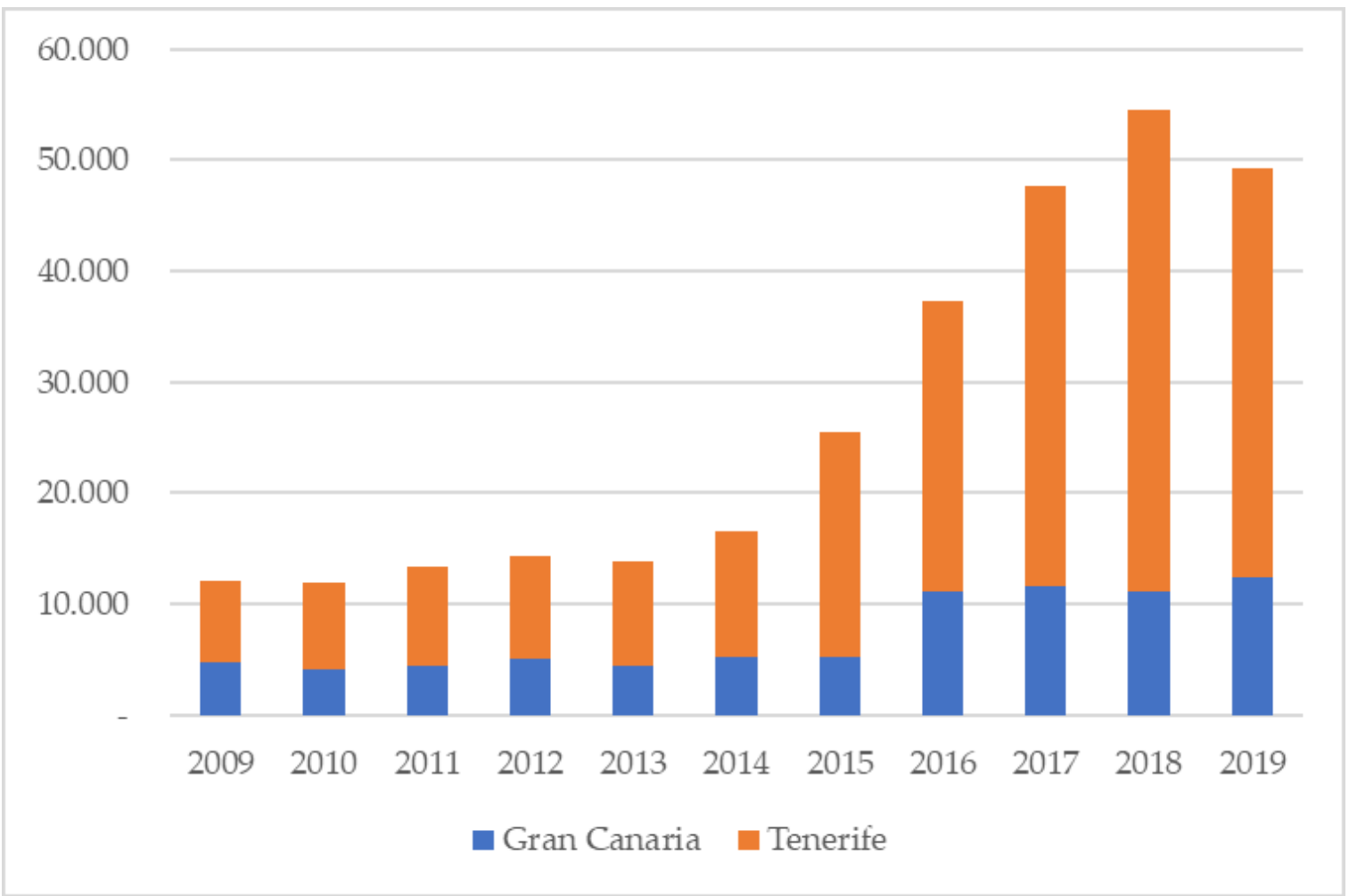

Mynd 2. Fjöldi Íslendinga sem ferðast til Kanaríeyja og vægi til Gran Canaria og Tenerife árin 2009-2019 (Heimild: ISTAC, e.d.)

Pessi próun er ekki ósvipuð pví sem gögn Ferðamálastofu gefa til kynna. Aukning koma Íslendinga til Kanaríeyja frá árinu 2012 til 2019 er pó miklu meiri en aukning fólks til Spánar eða Portúgals. Hún er um pað bil $400 \%$ á meðan að áætluð aukning fjölda íslenskra farpega til Spánar eða Portúgals var um 150\%. Pessi hlutföll eru ekki alveg sambærileg pví að Ferðamálastofa telur eingöngu fjölda Íslendinga en Hagstofan fjölda ferða. Par sem fjöldi ferðalaga hvers einstaklings árlega sem á annað borð fór til útlanda jókst um rúmlega 10\% á síðari hluta tímabilsins (Birkir Örn Gretarsson o.fl., 2020, bls. 24), pá er aukning koma til Kanaríeyja samanborið við fjölda fólks sem fór til Spánar eða Portúgals í pessu dæmi væntanlega ofmetin um 15-20\%. Prátt fyrir slíka „leiðréttingu“ í pessum samanburði er ljóst að vægi ferða til Kanaríeyja umfram aðra hluta Spánar og Portúgals jókst töluvert á pessum árum. Рað skýrist væntanlega af pví að margir fóru að fara oftar en einu sinni á ári, sérstaklega pegar flugfélagið WOW fór að bjóða afar ódýrar ferðir í beinu flugi til Tenerife og Gran Canaria, samhliða áframhaldandi framboði á pakkaferðum hjá ferðaskrifstofum til eyjanna (WOW hefur flug til Gran Canaria, 2015). I sumum tilfellum voru fargjöld hjá WOW jafnvel undir kostnaðarverði (Fargjöld til Kanarí undir kostnaðarverði, 2015). Einn mikilvægur páttur í pví hversu mikið aðdráttarafl ákveðnir staðir hafa er einmitt aðgengi að staðnum, í samspili við verð og vegalengd (Eyrún Jenný Bjarnadóttir, 2010, bls. 44).

Рó að vinsælt sé að ferðast til Kanaríeyja frá öllum Norðurlöndunum hafa Íslendingar á síðustu árum ferðast pangað í talsvert meira mæli en íbúar hinna Norðurlandanna. Pegar fjöldi ferða frá Norðurlöndunum til Kanaríeyja er skoðaður með hliðsjón af mannfjölda má sjá að árið 2019 voru að meðaltali 5,7 ferðir til Kanaríeyja á hverja 100 íbúa í Danmörku, Finnlandi, Noregi og Svípjóð, en 13,8 ferðir á hverja 100 íbúa á Íslandi (ISTAC, e.d.; Nordic statistics, e.d.). ${ }^{2}$

Flestir Íslendingar fóru til Kanaríeyja árið 2018 og var pá fjöldi koma íslensks ferðafólks rúmlega 350\% hærri en árið 2010. Tölur vegna Norðurlandabúa sýna að flestir fóru árið áður, 2017 og var aukningin pá miðað við árið 2010 um 45\%. Sambærilegar tölur fyrir 
alla ferðamenn (Spánarbúar á meginlandinu meðtaldir) sem fóru til Kanaríeyja sýna að aukningin á sama tímabili var tæplega 60\%. Árið 2019 var fjöldi koma Íslendinga tæplega tvöfaldur fjöldi miðað við árið 2015, en sá fjöldi hjá Norðurlandapjóðum var meira að segja minni árið 2019 en árið 2015 (ISTAC, e.d.).

Mynd 3 sýnir fjölda Norðurlandabúa sem ferðuðust til Kanaríeyja árin 2010-2019 samkvæmt upplýsingum Hagstofu Kanaríeyja.

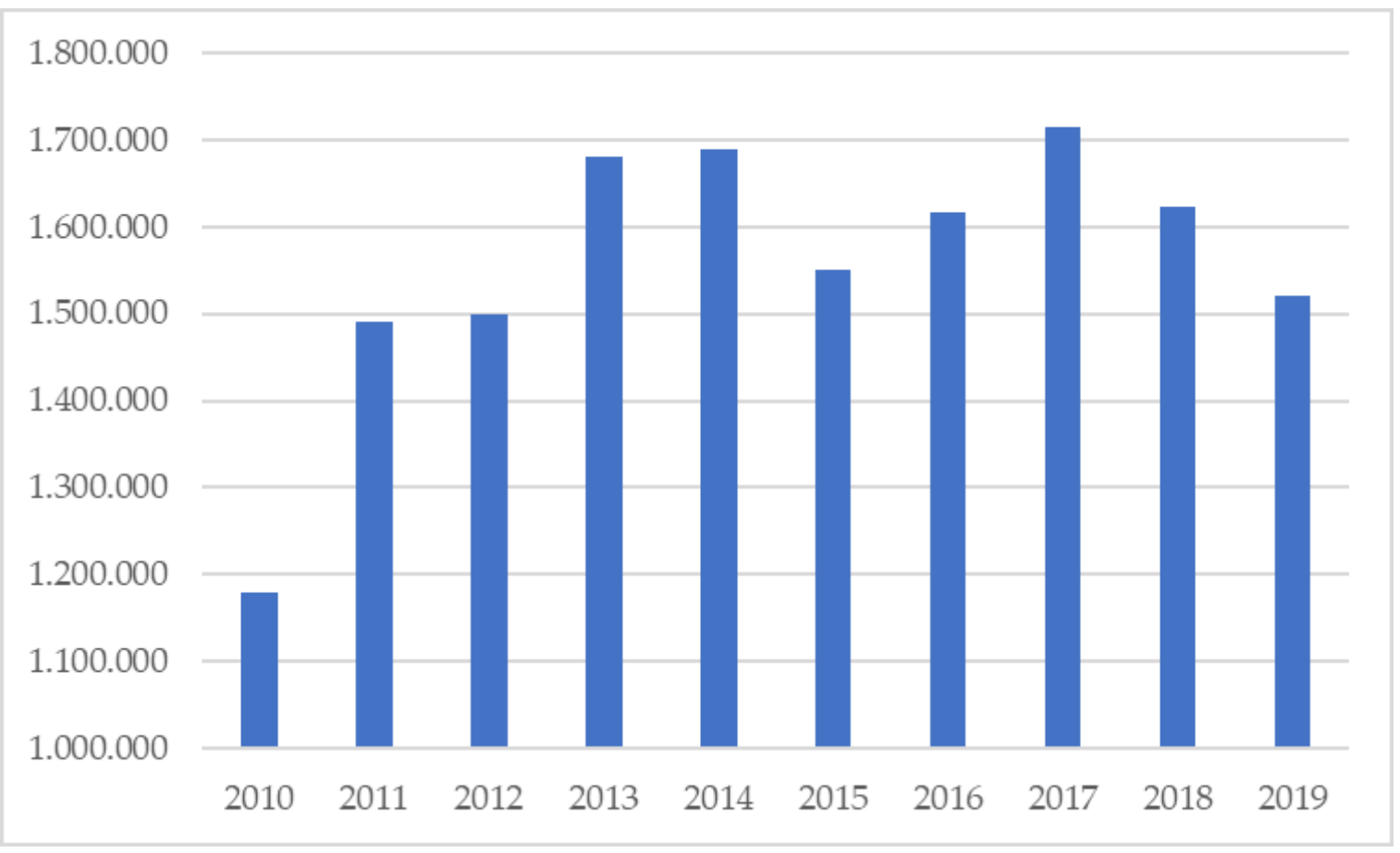

Mynd 3. Fjöldi koma frá Norðurlöndum til Kanaríeyja (Heimild: ISTAC, e.d.)

Einnig er vert að benda á að gjaldeyrishöft almennings voru að mestu afnumin árið 2015 og í framhaldinu styrktist íslenska krónan töluvert. Раð pýddi að bæði urðu flugferðir almennt ódýrari ${ }^{3}$ en einnig varð uppihald á sólarlandaströndum ódýrara en áður í íslenskum krónum talið.

Mynd 4 endurspeglar út frá tölum Hagstofu Kanaríeyja pá mánuði sem flogið er frá Íslandi til eyjanna. Hér má sjá að janúar-mars er pað tímabil sem flestir heimsækja eyjarnar, en aðsókn dregst niður á vormánuðum, eykst lítilega yfir sumarleyfismánuðina í júní og júlí og er pá um pað bil helmingur af pví sem á sér stað fyrstu prjá mánuði ársins. Eftir smá lægð á haustmánuðum tekur aðsókn Íslendinga pangað svo aftur stökk í október og desember pegar hún er um 20\% hærri en yfir annasömustu sumarmánuðina. 


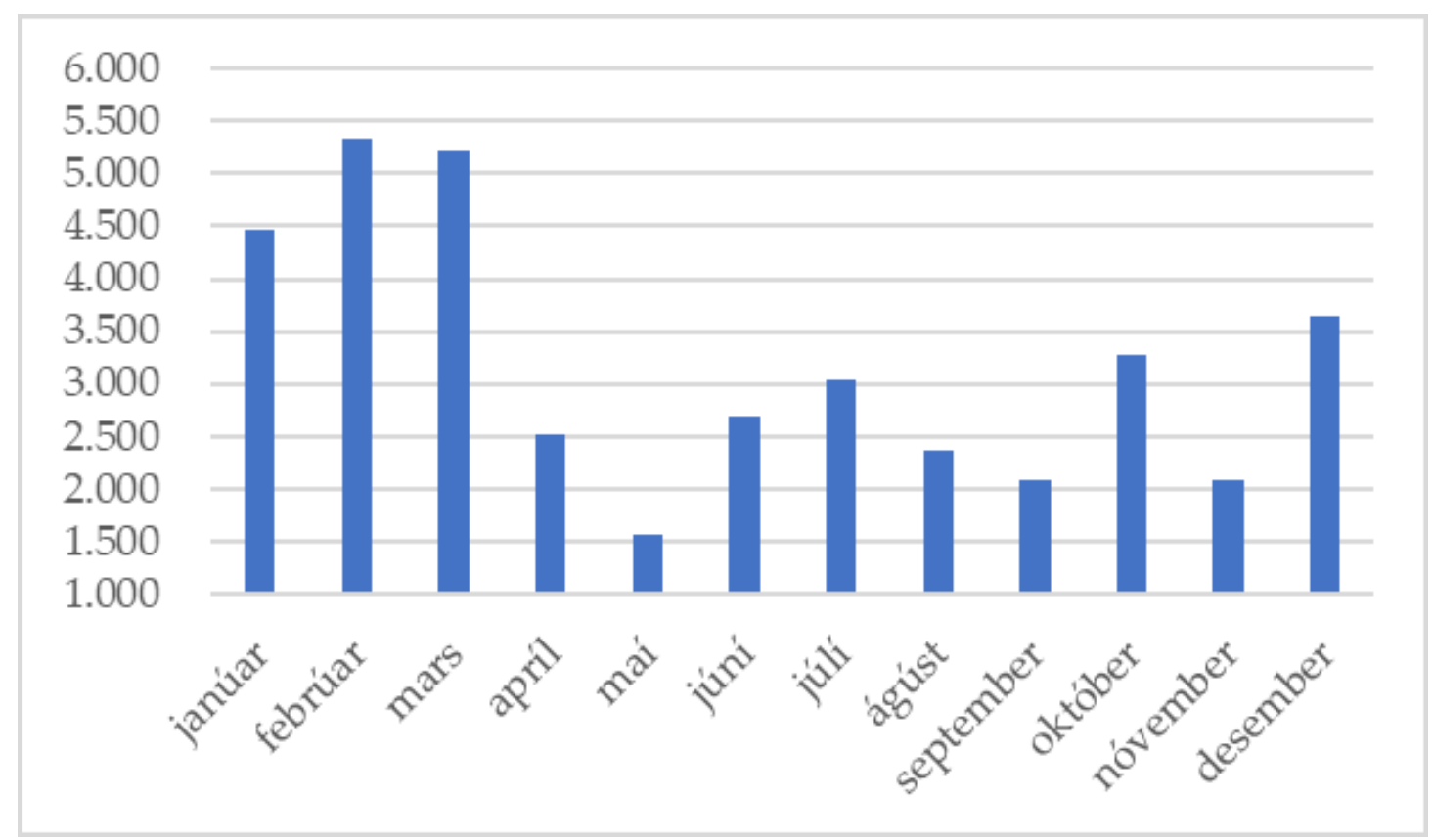

Mynd 4. Meðalfjöldi Íslendinga í hverjum mánuði sem fljúga til Kanaríeyja 2010-2019 (Heimild: ISTAC, e.d.)

Mynd 5 dregur saman komur frá 2009-2019, par sem jafnframt má sjá dreifingu út frá mánuðum. Sjá má að frá árinu 2009 til og með ársins 2015 koma farpegar frá Íslandi til Gran Canaria (blá svæði stólpanna) nær eingöngu yfir haust- og vetrarmánuðina en yfir allt árið til Tenerife (appelsínugul svæði stólpanna). Petta má líklega skýra með pví að beint flug til Tenerife hefur dreifst yfir á fleiri mánuði. Á myndinni sést að fáir koma frá Íslandi til Gran Canaria á sumrin fram til ársins 2015 og pó svo að pað séu einhverjar komur árin eftir, pá eru pær miklu færri í peim mánuðum. Langflestar komur til Gran Canaria eiga sér stað vetrarmánuðina í kringum janúar.

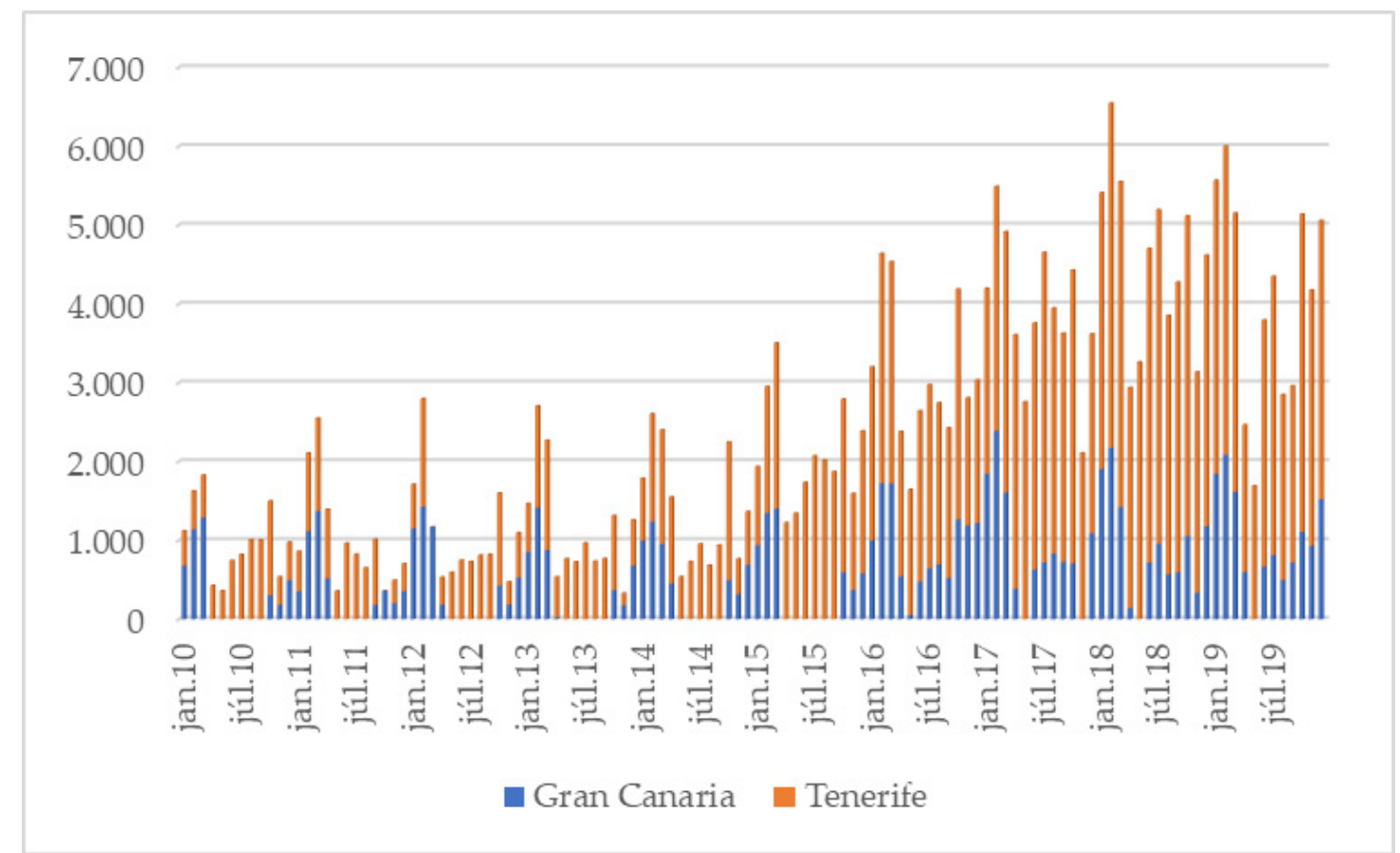

Mynd 5. Fjöldi koma frá Íslandi til Gran Canaria og Tenerife 2010-2019 skipt eftir mánuðum (Heimild: ISTAC, e.d.) 


\section{Gögn fengin með spurningakönnun árið 2019}

\section{1 Аðferðafræði}

Markmið spurningakönnunarinnar var að kanna almennt viðhorf og reynslu Íslendinga af ferðalögum til Kanaríeyja. Könnunin var lögð fyrir meðlimi í netpanel Félagsvísindastofnunar Háskóla Íslands, 11. mars 2019. I netpanel Félagsvísindastofnunar er fólk af öllu landinu sem hefur náð 18 ára aldri og hefur sampykkt að taka pátt í netkönnunum á vegum stofnunarinnar. Tekið var 1.998 manna lagskipt tilviljunarúrtak úr netpanelnum. Úrtakið var lagskipt eftir kyni, aldri og búsetu pannig að pað endurspeglaði sem best samsetningu landsmanna. Pátttakendur svöruðu 10 spurningum um ferðir til Kanaríeyja auk pess að svara ýmsum bakgrunnsspurningum. Alls svöruðu 924 einstaklingar könnuninni og er pátttökuhlutfall pví 46,2\%.

Er frá höfðu verið teknir peir sem ekki svöruðu lykilspurningum sem snéru að pví hvort peir hafi dvalið á Kanaríeyjum og peir sem gáfu ekki upp ferðaár, pá fækkaði í svarendahópi niður í 887 einstaklinga. Nokkuð var einnig um að pessir 887 einstaklingar slepptu pví að svara einstaka bakgrunnsspurningum s.s. kyni, aldri, fjölda barna á heimili og búsetu, pví er heildarfjöldi lítillega breytilegur í niðurstöðum. Líkt og sjá má í töflu 2, pá voru karlkyns pátttakendur alls 442 (50\% svarenda), og höfðu 51\% peirra ferðast til Kanaríeyja á lífsleiðinni og af pví úrtaki höfðu tæplega 68\% farið síðastliðin 10 ár (20092019). Svipaðar tölur má sjá meðal kvenkyns svarenda, par sem 255 af 435 konum (59\%) höfðu ferðast til Kanaríeyja og af peim höfðu 75\% farið til eyjanna á árunum 2009-2019.

Við úrvinnslu á niðurstöðum könnunarinnar er sjónum beint að peim svarendahópi sem ferðast hefur til eyjanna undanfarin 10 ár. Tafla 2 dregur fram með lýsandi tölfræði helstu einkenni pessa hóps, annars vegar fyrir karlkyns svarendur og hins vegar fyrir kvenkyns svarendur, en til samanburðar er unnt að skoða pá sem ekki hafa ferðast til eyjanna, sem og pann hóp sem óháð ártali hefur ferðast til eyjanna. Pegar ferðahópur síðustu 10 ára, alls 345 einstaklingar, er borinn saman við pann hóp svarenda sem ekki hefur ferðast til Kanaríeyja má sjá að hærra hlutfall svarenda er í hjónabandi og 66 ára og eldri.

Tafla 2. Lýsandi tölfræði yfir pátttakendur rannsóknar.

\begin{tabular}{|c|c|c|c|c|c|c|}
\hline & \multicolumn{2}{|c|}{$\begin{array}{l}\text { Svarendur sem ekki hafa } \\
\text { farið til Kanaríeyja }\end{array}$} & \multicolumn{2}{|c|}{$\begin{array}{l}\text { Svarendur sem farið hafa til } \\
\text { Kanaríeyja á lífsleiðinni }\end{array}$} & \multicolumn{2}{|c|}{$\begin{array}{l}\text { Svarendur sem farið hafa til } \\
\text { Kanaríeyja árin 2009-2019 }\end{array}$} \\
\hline & Karlar & Konur & Karlar & Konur & Karlar & Konur \\
\hline Fjöldi (N) & 217 & 180 & 225 & 255 & 155 & 190 \\
\hline \multicolumn{7}{|l|}{ Aldur } \\
\hline$<35$ & $28 \%$ & $41 \%$ & $27 \%$ & $38 \%$ & $22 \%$ & $33 \%$ \\
\hline $36-45$ & $23 \%$ & $16 \%$ & $17 \%$ & $12 \%$ & $18 \%$ & $13 \%$ \\
\hline $46-55$ & $20 \%$ & $16 \%$ & $17 \%$ & $18 \%$ & $16 \%$ & $18 \%$ \\
\hline $56-65$ & $17 \%$ & $16 \%$ & $15 \%$ & $13 \%$ & $16 \%$ & $17 \%$ \\
\hline $66-75$ & $8 \%$ & $5 \%$ & $15 \%$ & $9 \%$ & $16 \%$ & $10 \%$ \\
\hline $76>$ & $4 \%$ & $7 \%$ & $9 \%$ & $9 \%$ & $11 \%$ & $8 \%$ \\
\hline \multicolumn{7}{|l|}{ Búseta } \\
\hline Höfuðborgarsvæði & $63 \%$ & $62 \%$ & $64 \%$ & $69 \%$ & $62 \%$ & $67 \%$ \\
\hline Landsbyggðin & $37 \%$ & $38 \%$ & $36 \%$ & $31 \%$ & $38 \%$ & $33 \%$ \\
\hline \multicolumn{7}{|l|}{ Heimilistekjur } \\
\hline$<400$ pús & $22 \%$ & $29 \%$ & $19 \%$ & $25 \%$ & $15 \%$ & $18 \%$ \\
\hline 401-600 pús & $22 \%$ & $20 \%$ & $18 \%$ & $18 \%$ & $18 \%$ & $19 \%$ \\
\hline 601-900 pús & $18 \%$ & $24 \%$ & $18 \%$ & $23 \%$ & $22 \%$ & $27 \%$ \\
\hline 901-1100 pús & $15 \%$ & $8 \%$ & $10 \%$ & $11 \%$ & $12 \%$ & $13 \%$ \\
\hline 1101 pús> & $24 \%$ & $17 \%$ & $36 \%$ & $24 \%$ & $37 \%$ & $23 \%$ \\
\hline
\end{tabular}




\begin{tabular}{|c|c|c|c|c|c|c|}
\hline & \multicolumn{2}{|c|}{$\begin{array}{l}\text { Svarendur sem ekki hafa } \\
\text { farið til Kanaríeyja }\end{array}$} & \multicolumn{2}{|c|}{$\begin{array}{l}\text { Svarendur sem farið hafa til } \\
\text { Kanaríeyja á lífsleiðinni }\end{array}$} & \multicolumn{2}{|c|}{$\begin{array}{l}\text { Svarendur sem farið hafa til } \\
\text { Kanaríeyja árin 2009-2019 }\end{array}$} \\
\hline & Karlar & Konur & Karlar & Konur & Karlar & Konur \\
\hline \multicolumn{7}{|l|}{ Hjúskaparstaða } \\
\hline Einhleyp(ur) & $26 \%$ & $24 \%$ & $17 \%$ & $26 \%$ & $12 \%$ & $21 \%$ \\
\hline Í sambúð & $19 \%$ & $26 \%$ & $20 \%$ & $23 \%$ & $21 \%$ & $24 \%$ \\
\hline Hjónaband & $48 \%$ & $40 \%$ & $57 \%$ & $45 \%$ & $60 \%$ & $50 \%$ \\
\hline Skilin(n) eða ekkill/ekkja & $8 \%$ & $10 \%$ & $7 \%$ & $6 \%$ & $7 \%$ & $5 \%$ \\
\hline \multicolumn{7}{|l|}{ Börn á heimili } \\
\hline Engin börn & $58 \%$ & $64 \%$ & $64 \%$ & $56 \%$ & $68 \%$ & $57 \%$ \\
\hline Börn á heimili & $42 \%$ & $36 \%$ & $36 \%$ & $44 \%$ & $32 \%$ & $43 \%$ \\
\hline \multicolumn{7}{|l|}{ Menntun } \\
\hline Gunnskólamenntun & $32 \%$ & $27 \%$ & $28 \%$ & $30 \%$ & $28 \%$ & $28 \%$ \\
\hline Framhaldsskólamenntun & $41 \%$ & $34 \%$ & $43 \%$ & $35 \%$ & $46 \%$ & $34 \%$ \\
\hline Háskólamenntun & $27 \%$ & $39 \%$ & $29 \%$ & $35 \%$ & $27 \%$ & $38 \%$ \\
\hline \multicolumn{7}{|l|}{ Starfsstétt } \\
\hline Stjórnendur og sérfr. & $33 \%$ & $42 \%$ & $39 \%$ & $42 \%$ & $38 \%$ & $43 \%$ \\
\hline Skrifstofufólk & $21 \%$ & $11 \%$ & $26 \%$ & $12 \%$ & $26 \%$ & $12 \%$ \\
\hline Iðnaðarmenn, & $14 \%$ & $40 \%$ & $23 \%$ & $38 \%$ & $26 \%$ & $39 \%$ \\
\hline Bændur, verkafólk & $32 \%$ & $7 \%$ & $12 \%$ & $8 \%$ & $11 \%$ & $7 \%$ \\
\hline
\end{tabular}

\subsection{Niðurstöður spurningakönnunar}

Allir pátttakendur voru spurðir "hversu mikinn eða lítinn áhuga hefur pú á poí að fara til Kanaríeyja" og var svarkvarðinn 5 punkta Likert kvarði par sem 1=mjög lítinn áhuga og $5=$ =mjög mikinn áhuga. Sjá má í töflu 3 að konur $(\mathrm{M}=3,7 ; \mathrm{sf}=1,3)$ eru marktækt áhugasamari um að ferðast til Kanaríeyja en karlmenn $(\mathrm{M}=3,4 ; \mathrm{sf}=1.3), t(881)=2,94, p<.01)$. Áhugi á eyjunum er nokkuð óháður aldri svarenda.

Tafla 3. Hversu lítinn eða mikinn áhuga hefur pú á Kanaríeyjum, eftir kyni og aldri

\begin{tabular}{lccccccc}
\hline & $\begin{array}{c}\text { Mjög lítinn } \\
\text { áhuga }\end{array}$ & $\begin{array}{c}\text { Frekar lítinn } \\
\text { áhuga }\end{array}$ & Hlutlaus & $\begin{array}{c}\text { Frekar mikinn } \\
\text { áhuga }\end{array}$ & $\begin{array}{c}\text { Mjög mikinn } \\
\text { áhuga }\end{array}$ & $\begin{array}{c}\text { Meðaltal } \\
\text { (sf) }\end{array}$ & $\begin{array}{c}\text { Fjöldi } \\
\text { svarenda }\end{array}$ \\
\cline { 2 - 8 } Karlar & $10 \%$ & $16 \%$ & $19 \%$ & $33 \%$ & $23 \%$ & $3,4(1,3)$ & 443 \\
Konur & $9 \%$ & $12 \%$ & $16 \%$ & $26 \%$ & $37 \%$ & $3,7(1,3)$ & 441 \\
\hline Fjöldi & & & & & & & 884 \\
\hline 18-25 ára & $35 \%$ & $28 \%$ & $13 \%$ & $12 \%$ & $11 \%$ & $3,6(1,4)$ & 134 \\
26-35 ára & $28 \%$ & $26 \%$ & $15 \%$ & $21 \%$ & $10 \%$ & $3,4(1,4)$ & 164 \\
36-45 ára & $29 \%$ & $31 \%$ & $25 \%$ & $7 \%$ & $7 \%$ & $3,7(1,2)$ & 150 \\
$45-55$ ára & $26 \%$ & $32 \%$ & $21 \%$ & $14 \%$ & $7 \%$ & $3,6(1,2)$ & 154 \\
$56-65$ ára & $34 \%$ & $31 \%$ & $13 \%$ & $14 \%$ & $8 \%$ & $3,7(1,3)$ & 133 \\
66-75 ára & $30 \%$ & $33 \%$ & $19 \%$ & $12 \%$ & $6 \%$ & $3,7(1,2)$ & 84 \\
76 ára + & $22 \%$ & $27 \%$ & $14 \%$ & $19 \%$ & $19 \%$ & $3,1(1,5)$ & 64 \\
\hline Fjöldi & & & & & & 883 \\
\hline
\end{tabular}

Svarendur voru einnig spurðir hversu oft peir hafi ferðast til eyjanna á lífsleiðinni. Í töflu 4 má sjá að 49\% karlkyns svarenda og 41\% kvenkyns svarenda höfðu aldrei komið, en 15\% karla og 23\% kvenna höfðu ferðast pangað prisvar sinnum eða oftar á lífsleiðinni. 
Tafla 4. Hversu oft hefur pú komið til Kanaríeyja, eftir kyni

\begin{tabular}{lccccccc}
\hline & Aldrei & 1 sinni & 2 sinnum & $3-5$ sinnum & $6-10$ sinnum & 11 sinnum eða oftar & Fjöldi \\
\hline Karlar & $49 \%$ & $20 \%$ & $15 \%$ & $9 \%$ & $4 \%$ & $3 \%$ & 445 \\
Konur & $41 \%$ & $23 \%$ & $13 \%$ & $16 \%$ & $4 \%$ & $3 \%$ & 433 \\
\hline Fjöldi & 398 & 188 & 121 & 107 & 37 & 27 & 878 \\
\hline
\end{tabular}

Rýnt var í gögnin og var sá 345 manna hópur sem ferðast hefur til eyjanna á árunum 2009 til 2019 skoðaður nánar. Eins og sjá má í töflu 5 pá ferðaðist stór hluti svarenda, 62\%, með maka sínum, og einkum átti pað við um karlkyns svarendur (71\%). Mjög fáir ferðast til eyjanna einir, 3\% karlmanna og 1\% kvenna. Jafnframt var stór hópur svarenda í samvistum par við yngri börn sín (22\%) eða pau sem eldri eru (9\%).

Út frá greiningu á ferðahópum voru teknir saman prír meginflokkar ferðamanna og samanburður gerður á milli ferðavenja peirra. Fyrsti hópurinn, alls 44 einstaklingar, voru peir sem voru 35 ára eða yngri og hafa ekki barn á heimili sínu. Annar hópurinn, samtals 109 einstaklingar, samanstóð af einstaklingum sem voru á aldrinum 26 til 55 ára og höfðu barn/börn á heimili sínu. Vakin er athygli á pví að pessi ferðahópur hefur víðasta aldursbilið (alls 29 ár) en allir í hópnum eiga pað sameiginlegt að barn undir 18 ára aldri býr á heimili viðkomandi. Pannig gátu einstaklingar á aldrinum 26 ára til 35 ára, fallið annað hvort í hóp 1 ef án barns en í hóp 2 ef barn var á heimilinu. Í priðja lagi, ferðahópur sem samanstóð af einstaklingum 56 ára eða eldri án barna á heimili, alls voru 127 einstaklingar í pessum priðja hópi. Greining út frá flokkum ferðamanna sem ferðast hafa til Kanaríeyja á árunum 2009-2019, var pví út frá 280 einstaklingum. Aðra svarendur sem ferðast hafa til eyjanna á pessum árum, alls 57 einstaklingar, en falla ekki undir neinn af pessum premur skilgreindu ferðahópum, er pví að finna í niðurstöðum út frá kyni, aldri o.s.frv., en ekki pegar ferðahópar eru skoðaðir sérstaklega.

Pessi príflokkun á ólíkum ferðamarkhópum, bæði út frá aldri og hvort börn séu á heimili, endurspeglar hugsanlega ólíkar parfir og óskir sem ferðamenn og getur gefið gleggri mynd en greining eingöngu út frá heildarhóp.

Tafla 5. Ferðahóparnir sem fóru til Kanaríeyja, 2009-2019

\begin{tabular}{lccc|ccc}
\hline & Samtals & Karlar & Konur & $\begin{array}{c}<35 \text { ára } \\
\text { án barna á } \\
\text { heimili }\end{array}$ & $\begin{array}{c}26-55 \text { ára, } \\
\text { með börn } \\
\text { á heimili }\end{array}$ & $\begin{array}{c}56 \text { ára }< \\
\text { einstaklingar, án } \\
\text { barna á heimili }\end{array}$ \\
\hline Ég fór ein/einn & $2 \%$ & $3 \%$ & $1 \%$ & $5 \%$ & $0 \%$ & $2 \%$ \\
Með maka & $62 \%$ & $71 \%$ & $54 \%$ & $24 \%$ & $67 \%$ & $75 \%$ \\
Með barni/börnum <17 ára & $22 \%$ & $24 \%$ & $21 \%$ & $0 \%$ & $62 \%$ & $4 \%$ \\
Með barni/börnum 18 ára & $9 \%$ & $8 \%$ & $10 \%$ & $0 \%$ & $8 \%$ & $12 \%$ \\
Með foreldrum & $15 \%$ & $8 \%$ & $20 \%$ & $39 \%$ & $24 \%$ & $1 \%$ \\
Með systkini/systkinum & $14 \%$ & $13 \%$ & $14 \%$ & $37 \%$ & $13 \%$ & $7 \%$ \\
Með öðrum fjölskyldumeðlimum & $18 \%$ & $19 \%$ & $18 \%$ & $16 \%$ & $31 \%$ & $9 \%$ \\
Með vini/vinum & $17 \%$ & $23 \%$ & $12 \%$ & $39 \%$ & $16 \%$ & $10 \%$ \\
Með samstarfsfólki & $3 \%$ & $2 \%$ & $3 \%$ & $3 \%$ & $4 \%$ & $0 \%$ \\
Öðrum & $9 \%$ & $5 \%$ & $12 \%$ & $0 \%$ & $4 \%$ & $9 \%$ \\
\hline Fjöldi & $\mathbf{3 4 5}$ & $\mathbf{1 5 5}$ & $\mathbf{1 9 0}$ & $\mathbf{4 4}$ & $\mathbf{1 0 9}$ & $\mathbf{1 2 7}$ \\
\hline
\end{tabular}

Er litið er til pessara priggja ólíku ferðahópa má sjá á mynd 6 að pað eru einkum elsti ferðahópurinn, 56 ára og eldri, sem ferðast títt til eyjanna undanfarin 10 ár. Alls tilgreindu $36 \%$ pessa hóps að hafa farið pangað 6 sinnum eða oftar, samanborið við $4 \%$ peirra sem voru á aldrinum 26-55 ára með barn á heimilinu. 


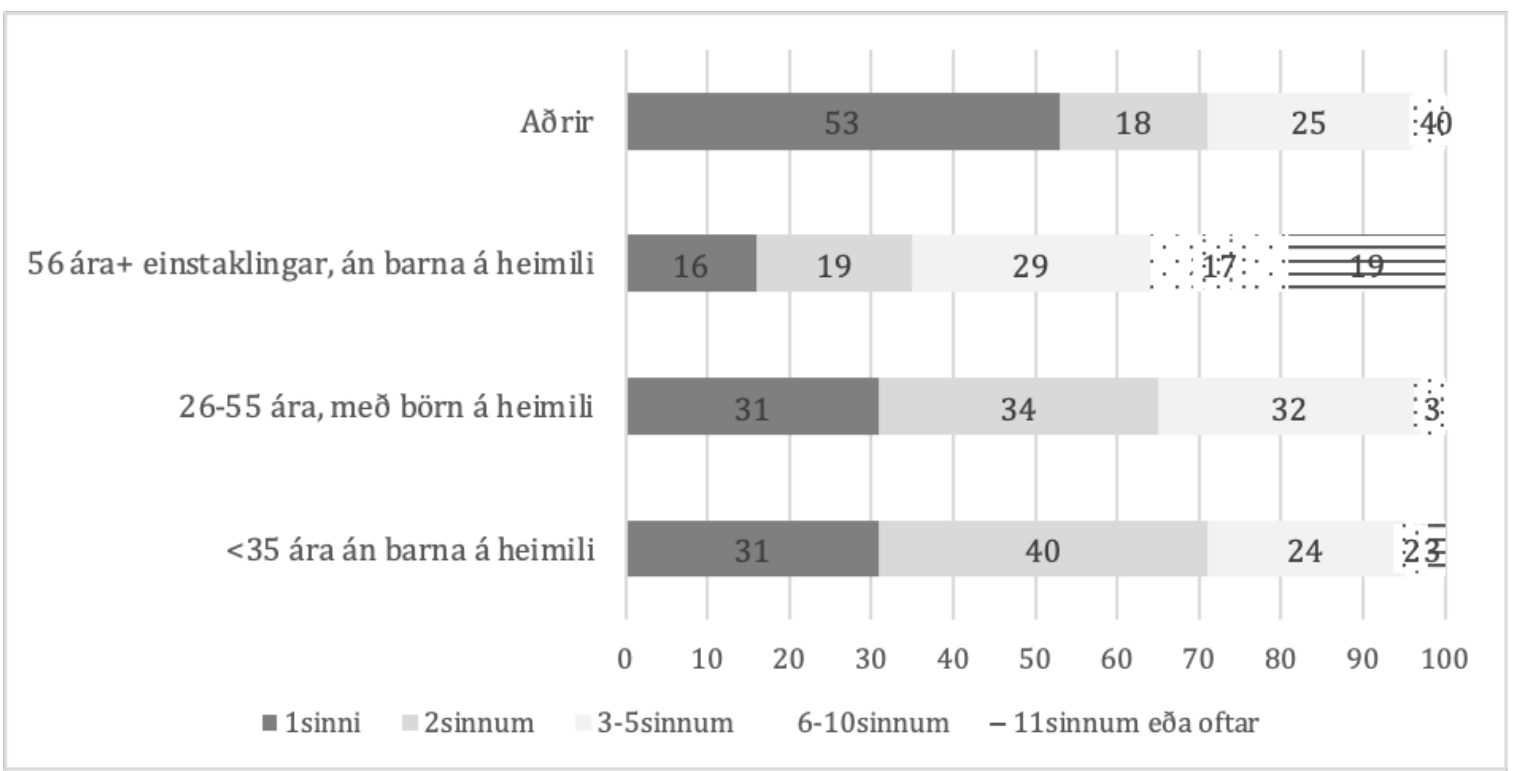

Mynd 6. Hversu oft hefur pú komið til Kanaríeyja, eftir ferðahópum og í prósentum

Auk pess var skoðað, meðal peirra ferðamanna sem farið hafa til eyjanna undanfarin 10 ár, hvaða eyjur urðu fyrir valinu (sjá töflu 6), og eru pað einkum Gran Canaria og Tenerife. Auk pess var borið saman hvort tíðni ferða til eyjanna sé ólík eftir áfangastað (sjá mynd 7).

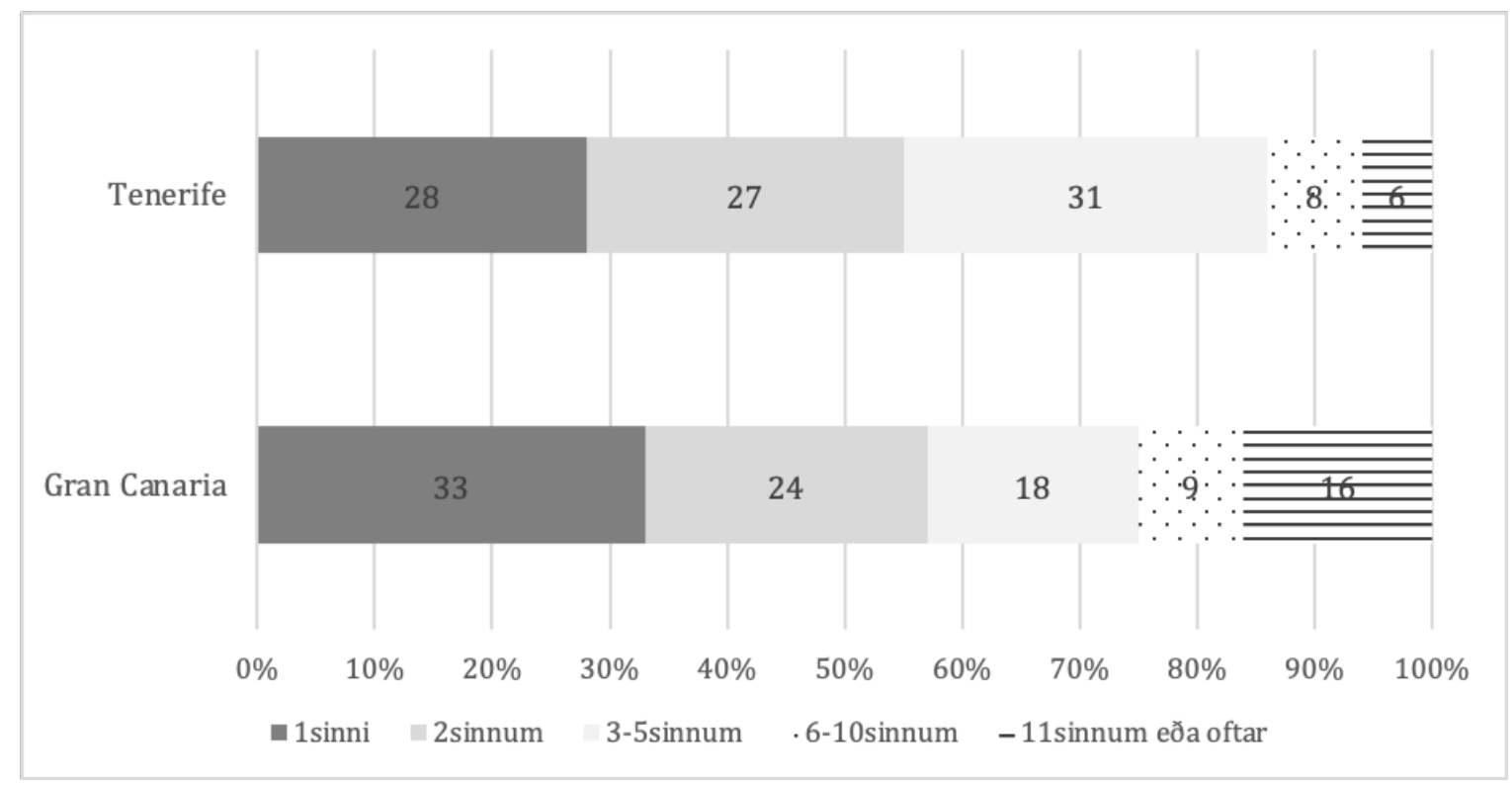

Mynd 7. Hversu oft hefur pú komið til Kanaríeyja, eftir eyju sem ferðast er til og í prósentum

Auk pess var athugað hvenær á árinu ferðast var til Kanaríeyja og til hvaða eyju, meðal pess 341 manns hóps sem farið hefur pangað undanfarin 10 ár (sjá töflu 6). Sjá má í ferðamannastraumi Íslendinga að tvær eyjar skera sig úr, Gran Canaria (N=68) og Tenerife (N=265). Af peim 68 sem ferðast hafa til Gran Canaria má sjá að pað er einkum í febrúar (24\%) og marsmánuði (16\%), auk júlí (12\%) sem eyjan er heimsótt. Stærri hópur svarenda hefur ferðast til Tenerife, alls 265 svarenda, og má sjá að pað eru bæði dimmir vetramánuðir (janúar 10\%, febrúar 11\%, mars 8\%) og bjartari sumarmánuðir (júní 11\%, júlí 13\%, ágúst $8 \%$ og september $10 \%$ ) sem verða fyrir valinu. Er litið er til ferðahópanna okkar priggja, eru pað einkum yngri og barnslausu ferðamennirnir sem dvelja á eyjunum á sumarmán- 
uðum, en peir sem eru 56 ára og eldri og án barna dreifast jafnar yfir árið í sínum ferðum, pó stærri hluti (19\%) kjósa að dvelja á Kanaríeyjum í febrúar mánuði.

Tafla 6. Hvenær á árinu ferðaðist pú til Kanaríeyja og til hvaða eyju var ferðast 2009-2019

\begin{tabular}{lcccc|ccc}
\hline & Gran Canaria & Tenerife & Adrar eyjar & Fjöldi & $<35$, án barna & $\mathbf{2 6 - 5 5 , ~} \mathbf{m} / \mathbf{b o ̈ r n u m}$ & $\mathbf{5 6}<$, án barna \\
\cline { 2 - 7 } Janúar & $9 \%$ & $10 \%$ & $13 \%$ & $10 \%$ & $6 \%$ & $10 \%$ & $14 \%$ \\
Febrúar & $24 \%$ & $11 \%$ & $25 \%$ & $13 \%$ & $0 \%$ & $9 \%$ & $19 \%$ \\
Mars & $16 \%$ & $8 \%$ & 0 & $9 \%$ & $16 \%$ & $5 \%$ & $9 \%$ \\
Apríl & $9 \%$ & $4 \%$ & 0 & $5 \%$ & $3 \%$ & $1 \%$ & $4 \%$ \\
Maí & $4 \%$ & $5 \%$ & 0 & $5 \%$ & $3 \%$ & $5 \%$ & $3 \%$ \\
Júní & $2 \%$ & $11 \%$ & 0 & $9 \%$ & $25 \%$ & $10 \%$ & $5 \%$ \\
Júlí & $12 \%$ & $13 \%$ & 0 & $12 \%$ & $15 \%$ & $16 \%$ & $9 \%$ \\
Ágúst & $2 \%$ & $8 \%$ & $25 \%$ & $7 \%$ & $14 \%$ & $10 \%$ & $2 \%$ \\
September & $4 \%$ & $10 \%$ & 0 & $9 \%$ & $13 \%$ & $10 \%$ & $6 \%$ \\
Október & $4 \%$ & $7 \%$ & $25 \%$ & $7 \%$ & $2 \%$ & $8 \%$ & $9 \%$ \\
Nóvember & $7 \%$ & $5 \%$ & 0 & $5 \%$ & $0 \%$ & $5 \%$ & $9 \%$ \\
Desember & $7 \%$ & $9 \%$ & $13 \%$ & $8 \%$ & $0 \%$ & $12 \%$ & $9 \%$ \\
\hline Fjöldi & $\mathbf{6 8}$ & $\mathbf{2 6 5}$ & $\mathbf{8} \%$ & $\mathbf{3 4 1}$ & $\mathbf{4 4}$ & $\mathbf{1 0 9}$ & $\mathbf{1 2 7}$ \\
\hline
\end{tabular}

Einnig var litið til pess hversu lengi ferðamenn dvöldu á staðnum (sjá töflu 7). Par má sjá að yngra fólk án barna er í stuttum 7 daga (38\%) eða 14 daga (55\%) ferðum, en peir sem tilheyra elsta aldurshópnum dvelja lengur í hvert sinn. Pó eru mjög fáir sem eru lengur en mánuð í einu (2\%).

Tafla 7. Hversu löng var dvölin hjá Íslendingum sem ferðuðust til Kanaríeyja 2009-2019

\begin{tabular}{lccccccc}
\hline & $<$ 7 dagar & $\mathbf{8 - 1 4}$ dagar & 15-21 dagar & 22-31 dagar & $\mathbf{1 . 1 - 3}$ mán & 3.1 mán< & Fjöldi \\
\hline$<35$ ára, án barna & $38 \%$ & $55 \%$ & $3 \%$ & $0 \%$ & $0 \%$ & $3 \%$ & 43 \\
$26-55$ ára, með börnum & $27 \%$ & $69 \%$ & $4 \%$ & $0 \%$ & $0 \%$ & $0 \%$ & 108 \\
$56<$, án barna & $14 \%$ & $55 \%$ & $18 \%$ & $11 \%$ & $2 \%$ & $0 \%$ & 128 \\
\hline Karlar & $24 \%$ & $59 \%$ & $11 \%$ & $5 \%$ & $0,5 \%$ & $0,5 \%$ & 155 \\
Konur & $24 \%$ & $61 \%$ & $10 \%$ & $4 \%$ & $0 \%$ & $1 \%$ & 189 \\
\hline
\end{tabular}

Áhugavert er að skoða hvaða ástæður svarendur gáfu fyrir ferð sinni til Kanaríeyja og var pað greint eftir kyni og eftir ferðahópunum premur (sjá töflu 8). Karlkyns svarendur gáfu einkum upp ástæðuna gott veður (65\%) og fjölbreytt afpreying fyrir fullorðna (9\%), en kvenkyns svarendur gott veðurfar (59\%) og að ferðin hafi verið á góðum kjörum (11\%). Er litið er til ferðahópanna priggja pá draga svör peirra keim af einkennum hópsins. Yngri svarendur án barna tiltóku meginástæðuna vera gott veðurfar $(38 \%)$ sem er pó talsvert sjaldnar nefnt en í eldri svarendahópum. Yngri svarendur nefndu jafnframt fjölbreytta afpreyingu fyrir fullorðna (21\%), að ferðin væri á góðum kjörum (11\%) og að eyjarnar hafi áhugaverða menningu og samfélag (11\%). Hjá ferðahópi peirra sem talist geta miðaldra og með börn, virðist gott veðurfar vega pyngst (62\%) og pví næst að ferðir til Kanaríeyja séu á góðum kjörum (12\%). Meðal elsta ferðahópsins, 56 ára og eldri án barna, er pað einkum veðurfar sem horft er til (70\%) en aðrir pættir fengu lítið vægi. 
Tafla 8. Ástæða fyrir að Kanaríeyjar verða fyrir valinu, eftir ferðahópum

\begin{tabular}{lccc|ccc}
\hline & Samtals & Karlar & Konur & $\begin{array}{c}<35 \text { ára } \\
\text { án barna }\end{array}$ & $\begin{array}{c}\mathbf{2 6 - 5 5} \text { ára, } \\
\text { með börn }\end{array}$ & $\begin{array}{c}56 \text { ára }< \\
\text { án barna }\end{array}$ \\
\hline Fjölbreytt afpreying í boði fyrir börn & $4 \%$ & $4 \%$ & $3 \%$ & $2 \%$ & $8 \%$ & $1 \%$ \\
Fjölbreytt afpreying fyrir fullorðna & $6 \%$ & $9 \%$ & $3 \%$ & $21 \%$ & $0 \%$ & $7 \%$ \\
Gott veðurfar & $61 \%$ & $65 \%$ & $59 \%$ & $38 \%$ & $62 \%$ & $70 \%$ \\
Ferðin var á góðum kjörum & $9 \%$ & $8 \%$ & $11 \%$ & $11 \%$ & $12 \%$ & $5 \%$ \\
Áhugaverð menning og samfélag & $2 \%$ & $1 \%$ & $3 \%$ & $11 \%$ & $0 \%$ & $2 \%$ \\
Falleg náttúra & $1 \%$ & $0 \%$ & $1 \%$ & $3 \%$ & $1 \%$ & $1 \%$ \\
Heimsæki ættingja og vini & $3 \%$ & $3 \%$ & $3 \%$ & $3 \%$ & $5 \%$ & $2 \%$ \\
Heilsufarsástæður & $2 \%$ & $1 \%$ & $3 \%$ & $0 \%$ & $0 \%$ & $5 \%$ \\
Vinna & $1 \%$ & $0 \%$ & $3 \%$ & $2 \%$ & $3 \%$ & $0 \%$ \\
Önnur ástæða & $10 \%$ & $9 \%$ & $12 \%$ & $10 \%$ & $10 \%$ & $9 \%$ \\
\hline Samtals fjöldi (N) & $\mathbf{3 4 3}$ & $\mathbf{1 5 2}$ & $\mathbf{1 9 1}$ & $\mathbf{4 4}$ & $\mathbf{1 0 9}$ & $\mathbf{1 2 7}$ \\
\hline
\end{tabular}

Pátttakendur voru spurðir hvað peir hefðu gert sér til dægradvalar er peir dvöldu síðast á eyjunum og var pað greint eftir kyni og ferðahópum (sjá töflu 9). Er litið var til hópsins í heild virðist sem $2 / 3$ svarenda dvelji á hóteli með fullu eða hálfu fæði (62\%) og afpreying fólst einkum í að liggja í sólbaði (93\%), fara á ströndina (83\%), versla fatnað (69\%) og sækja bari og skemmtistaði (61\%). Menningarlegri viðburðir líkt og að sækja tónleika og sýningar (9\%), fara í höfuðborg eyjanna (45\%) og fara í skoðunarferðir um eyjuna (18\%) eru minna sóttir. Örlítil blæbrigði má greina ef karlkyns og kvenkyns svarendur eru bornir saman, par sem konur tilgreina fremur að stunda hreyfingu $(45 \%)$ og verslun $(74 \%)$ en karlkyns svarendur. Ef litið er til ferðahópanna priggja eru peir sem elstir eru líklegri til að velja annan dvalarmáta en hótel með fullu eða hálfu fæði (59\%) en aðrir svarendur. Peir leggja ríkari stund á skipulagðar skoðunarferðir (26\%) og leigja sér síður bíl til að ferðast um eyjuna (24\%). Elsti hópurinn greinir jafnframt frá pví að hreyfing sé meira stunduð (44\%), en minna er um ferðir á strönd (69\%) eða liggja í sólbaði (87\%) en hjá öðrum hópum sem dæmi.

Tafla 9. Hvað gerðir pú í pinni síðustu ferð til Kanaríeyja, eftir kyni og ferðahópum

\begin{tabular}{lccc|ccc}
\hline & Samtals & Karlar & Konur & $\begin{array}{c}<35 \text { ára án } \\
\text { barna }\end{array}$ & $\begin{array}{c}\mathbf{2 6 - 5 5} \text { ára, } \\
\text { með börn }\end{array}$ & $\begin{array}{c}\mathbf{5 6} \text { ára< } \\
\text { án barna }\end{array}$ \\
\hline Gisti á hóteli með fullu eða hálfu fæði & $62 \%$ & $63 \%$ & $61 \%$ & $60 \%$ & $62 \%$ & $59 \%$ \\
Fór í skoðunarferð með farastjóra & $18 \%$ & $16 \%$ & $18 \%$ & $17 \%$ & $7 \%$ & $26 \%$ \\
Fór til höfuðborgar eyjanna & $45 \%$ & $42 \%$ & $47 \%$ & $63 \%$ & $49 \%$ & $40 \%$ \\
Leigði bílaleigubíl & $32 \%$ & $27 \%$ & $35 \%$ & $43 \%$ & $42 \%$ & $24 \%$ \\
Spilaði minigolf & $28 \%$ & $29 \%$ & $28 \%$ & $35 \%$ & $39 \%$ & $22 \%$ \\
Stundaði hreyfingu (t.d. hlaupa, hjóla, ...) & $40 \%$ & $33 \%$ & $45 \%$ & $33 \%$ & $33 \%$ & $44 \%$ \\
Fór á strönd & $83 \%$ & $82 \%$ & $83 \%$ & $97 \%$ & $91 \%$ & $69 \%$ \\
Fór í sólbað & $93 \%$ & $93 \%$ & $93 \%$ & $100 \%$ & $96 \%$ & $87 \%$ \\
Fór á safn & $7 \%$ & $9 \%$ & $5 \%$ & $3 \%$ & $2 \%$ & $7 \%$ \\
Fór í skemmtigarð eða dýragarð & $46 \%$ & $43 \%$ & $48 \%$ & $70 \%$ & $74 \%$ & $16 \%$ \\
Fór á tónleika eða sýningu & $9 \%$ & $8 \%$ & $10 \%$ & $10 \%$ & $10 \%$ & $11 \%$ \\
Verslaði föt & $69 \%$ & $63 \%$ & $74 \%$ & $87 \%$ & $79 \%$ & $56 \%$ \\
Fór á bar eða skemmtistað & $61 \%$ & $65 \%$ & $57 \%$ & $75 \%$ & $60 \%$ & $58 \%$ \\
Heimsótti fjölskyldu og vini sem búa par & $5 \%$ & $4 \%$ & $6 \%$ & $3 \%$ & $6 \%$ & $5 \%$ \\
\hline Fjöldi & 345 & $\mathbf{1 5 5}$ & $\mathbf{1 9 0}$ & $\mathbf{4 4}$ & $\mathbf{1 0 9}$ & $\mathbf{1 2 7}$ \\
\hline
\end{tabular}

Athugað var hvort munur væri á valinni dægradvöl eftir pví hvort ferðast væri til Gran Canaria eða Tenerife (sjá töflu 10). Par má einkum sjá að hópurinn sem dvelur á Gran 
Canaria velur sjaldnar hótel með fullu eða hálfu fæði (41\%) en peir sem ferðast til Tenerife (68\%), fara síður í skemmtigarða og dýragarða (20\%) og versla síður fatnað (60\%).

Tafla 10. Hvað gerðir pú í pinni síðustu ferð til Kanaríeyja, eftir eyjum

\begin{tabular}{lccc}
\hline & Samtals & Gran Canaria & Tenerife \\
\hline Gisti á hóteli með fullu eða hálfu fæði & $62 \%$ & $41 \%$ & $68 \%$ \\
Fór í skoðunarferð með farastjóra & $18 \%$ & $17 \%$ & $19 \%$ \\
Fór til höfuðborgar eyjanna & $45 \%$ & $41 \%$ & $46 \%$ \\
Leigði bílaleigubíl & $32 \%$ & $28 \%$ & $33 \%$ \\
Spilaði mini-golf & $28 \%$ & $27 \%$ & $29 \%$ \\
Stundaði hreyfingu (t.d. hlaupa, hjóla, fjallganga) & $40 \%$ & $46 \%$ & $38 \%$ \\
Fór á strönd & $83 \%$ & $81 \%$ & $83 \%$ \\
Fór í sólbað & $93 \%$ & $91 \%$ & $93 \%$ \\
Fór á safn & $7 \%$ & $6 \%$ & $7 \%$ \\
Fór í skemmtigarð eða dýragarð & $46 \%$ & $20 \%$ & $52 \%$ \\
Fór á tónleika eða sýningu & $9 \%$ & $10 \%$ & $9 \%$ \\
Verslaði föt & $69 \%$ & $60 \%$ & $72 \%$ \\
Fór á bar eða skemmtistað & $61 \%$ & $66 \%$ & $60 \%$ \\
Heimsótti fjölskyldu og vini sem búa á Kanaríeyjum & $5 \%$ & $13 \%$ & $3 \%$ \\
\hline Fjöldi & 345 & 70 & $\mathbf{2 6 9}$ \\
\hline
\end{tabular}

Að lokum er áhugavert að skoða aftur heildarsvarendur könnunarinnar með tilliti til pess hvað peir telji að íslenskir ferðamenn geri sér til dægrastyttingar er á Kanaríeyjum er dvalið. Eins og sjá má í töflu 11, pá var litið til svarendahópsins í heild ( $\mathrm{N}=885)$, peirra sem aldrei hafa komið til eyjana ( $\mathrm{N}=397)$, og peirra sem hafa ferðast til eyjanna á lífsleiðinni $(\mathrm{N}=480)$, og aftur svo peirra sem greint var frá að ofan og hafa verið á eyjunum á árunum 2009-2019. Mjög ápekk svörun kom fram hjá öllum hópum, sem bendir til að skilningur peirra sem ekki hafa ferðast til eyjanna speglar upplifun peirra sem par hafa dvalið. Slíkt endurspeglar ákveðna sýn á Kanaríeyjar sem áfangstað sem snýr fyrst og fremst að sól og strönd. Eingöngu 1\% svarenda taldi íslenska ferðamenn fara á söfn á Kanaríeyjum og enginn peirra sem hafði farið á eyjarnar taldi ferðmenn fara á söfn, sem er í andstöðu við niðurstöður um hvað fólk gerði sjálft eins og sjá má í töflu 2 sem sýnir að 7\% peirra sem fara á Kanarí hafa heimsótt söfn.

Tafla 11. Hvað heldur pú að íslenskir ferðamenn geri sér til dægrastyttingar á Kanaríeyjum

\begin{tabular}{lcccc}
\hline & Samtals & $\begin{array}{c}\text { Peir sem aldrei } \\
\text { hafa farið }\end{array}$ & $\begin{array}{c}\text { Peir sem } \\
\text { hafa farið }\end{array}$ & $\begin{array}{c}\text { Peir sem hafa farið á } \\
\text { síðustu 10 árum }\end{array}$ \\
\hline Fari á ströndina & $80 \%$ & $82 \%$ & $77 \%$ & $78 \%$ \\
Fari í skipulagðar skoðunarferðir & $18 \%$ & $19 \%$ & $17 \%$ & $16 \%$ \\
Fari á söfn, leikhús, tónleika eða aðra & $1 \%$ & $1 \%$ & $0 \%$ & $0 \%$ \\
menningarviðburði & & & & $7 \%$ \\
Stundi ípróttir (hjóla, hlaupa, ...) & $7 \%$ & $7 \%$ & $6 \%$ & $47 \%$ \\
Fari út að skemmta sér & $42 \%$ & $38 \%$ & $47 \%$ & $32 \%$ \\
Kaupi föt, skó og fylgihluti & $27 \%$ & $21 \%$ & $31 \%$ & $4 \%$ \\
Heimsæki fjölskyldi og vini sem búa par & $3 \%$ & $2 \%$ & $4 \%$ & $59 \%$ \\
Gisti á hóteli með fullu eða hálfu fæði & $61 \%$ & $62 \%$ & $60 \%$ & $2 \%$ \\
Annað & $2 \%$ & $7 \%$ & $2 \%$ & 345 \\
\hline Fjöldi & 885 & 397 & 480 & $2 \%$ \\
\hline
\end{tabular}




\section{Samantekt og umræða}

Vaxandi ferðamennska á heimsvísu hefur verið mikilvægur hluti hnattrænna ferla síðustu áratugi. Á Íslandi hefur fjöldi ferða til útlanda að sama skapi aukist verulega eða frá pví að innan við 50\% landsmanna fóru til útlanda á árinu 2009 til 80\% árið 2019 (Birkir Örn Gretarsson o.fl., 2020).

Pessi grein afmarkaðist við rannsóknarspurninguna: Hvað einkennir ferðir Íslendinga til Kanaríeyja síðasta áratuginn og hverskonar áfangastadur eru Kanarieyjar fyrir Íslendinga? Eins og sýnt er fram á hafa Islendingar ferðast til Kanaríeyja í langan tíma, að minnsta kosti allt frá miðri síðustu öld, en skipulagðar ferðir til eyjanna hófust um miðjan sjöunda áratuginn. Par fylgdu Íslendingar í kjölfar annarra Norðurlandabúa sem hafa verið mikilvægur ferðamannahópur á Kanaríeyjum frá upphafi fjöldaferðamennsku til eyjanna. Ferðir til Kanarí jukust jafnt og pétt frá 2009 og tóku svo stökk upp á við 2015. Af tölum frá Hagstofu Kanarí og Ferðamálastofu Íslands að dæma eru Íslendingar einkum að ferðast til tveggja eyja, Gran Canaria og Tenerife, en vinsældir Tenerife hafa aukist jafnt og pétt og hafa á síðastliðnum árum verið mun vinsælli sem áfangastaður Íslendinga en Gran Canaria. Gögn Ferðamálastofu endurspegla að ferðir til Spánar/Portúgal hafa á síðastliðnum 10 árum orðið stærra hlutfall af heildarfjölda utanlandsferða. Gögnin frá Hagstofu og Ferðamálastofu upplýsa ekki um tilgang pessara ferða né um hlutfall ferðafólks út frá peim Íslendingum sem búa að hluta til á eyjunum en hafa má í huga að erlendar rannsóknir sýna að mörk milli peirra Norður Evrópubúa sem fara sem ferðamenn og peirra sem búa eða starfa að hluta til á Spáni eru flæðandi og pannig oft erfitt að aðgreina milli pessa hópa.

Рað kemur ekki á óvart að niðurstöður spurningakönnunarinnar gefa til kynna að viðhorf Íslendinga gagnvart ferðalögum til eyjanna er almennt jákvætt. Petta jákvæða viðhorf er óháð aldri, pó konur séu marktækt áhugasamari um að ferðast til Kanaríeyja en karlmenn. Lengi vel hefur loðað sú ímynd við Kanaríeyjar að pær væru mestmegins sóttar af eldra fólki (til dæmis í samhengi við Gran Canaria, Freysteinn Jóhannsson, 1995, bls. 6). Eigindlegar niðurstöður endurspegla petta en pó er einnig töluvert um að barnafólk heimsækir eyjurnar.

Yngri og barnlausi hópurinn sækir einkum í ferðalög að sumarlagi (júní-september) en mjög fátítt er að pessi hópur ferðist til eyjanna að vetrarlagi. Pessi hópur dvelur stutt á eyjunum, 93\% í 14 daga eða skemur. Meginástæðan sem pessi hópur gefur fyrir pví að ferðast til Kanaríeyja er gott veðurfar (38\%) og fjölbreytt afpreying fyrir fullorðna (21\%). Góð kjör virðast ekki skipta meginmáli í vali á ferðinni (11\%) og einnig var áhugaverð menning og samfélag eingöngu gefin upp af $11 \%$ sem meginástæða fyrir aðdráttarafli eyjanna. Yngsti hópurinn hefur aðeins aðrar ferðavenjur en peir sem eldri eru eða barnafólk. Peir ferðast oftar til höfuðborga eyjanna og leggja mikla stund á sólböð $(100 \%)$ og strandferðir $(97 \%)$ auk pess að versla fatnað (87\%) og sækja bari eða skemmtistaði $(75 \%)$. Dvöl peirra sem eldri eru var lengri, 31\% peirra dvöldu lengur en 15 daga, en pó dvöldu eingöngu $2 \%$ lengur en einn mánuð. Ferðatími pessa hóps er oftast í janúar eða febrúar sem er vísbending um að margir eru eftirlaunapegar og eiga pví hægara með að ferðast á veturna. Sá stutti tími sem dvalist er gefur pó vísbendingu um að eftirlaunapegar frá Íslandi eru almennt ekki að dveljast langdvölum á Kanarí sem er nokkuð ólíkt pví sem gerist hvað varðar Norður-Evrópupjóðir almennt. Petta pyrfti pó að skoða mun betur. Meginástæða pessa hóps fyrir vali á Kanarí sem áfangastaðar er gott veðurfar (70\%) en aðrar ástæður fyrir vali fá lága almenna svörun. Er litið er til peirrar afpreyingar sem eldri og barnlausir ferðamenn tilgreina að hafi einkennt peirra síðustu ferð til eyjanna, má sjá að strandferðir eru síður tilgreindar (69\%) en hjá yngra fólki pó sólböðun sé með álíka hætti (87\%). Pessi hópur greinir jafnframt síður frá verslunarferðum (56\%), ferðum í skemmtigarða (16\%), eða leigu á bílaleigubílum (24\%) til að keyra á eigin vegum um eyjuna sem heimsótt hefur verið. Pessi hópur virðist fremur sækja í að stunda markvissa hreyfingu s.s. golf og göngu (44\%). Gott veðurfar er í raun talin upp sem langmikilvægasta ástæða pess hjá öllum svarendum að eyjarnar urðu fyrir valinu eða hjá $61 \%$ páttakenda.

Meginniðurstöður rannsóknarinnar endurspegla pannig að fyrir Íslendinga er aðdrátt- 
arafl Kanaríeyja sem áfangastaðar fyrst og fremst í tengslum við veðurfar eyjanna og afpreyingu sem tengist í flestum tilfellum sólarlandaferðum, p.e. fara á strönd eða liggja í sólböðum. Petta er áhugavert í ljósi pess að prátt fyrir að Spánn hafi lengi vel lagt áherslu á landið sem áfangastað peirra sem sóttust eftir strönd og sól, hefur eftir 1990 verið reynt að leggja ríkari áherslu á fleiri pætti svo sem menningu Spánar og náttúru í víðari skilningi (Andreu o.fl., 2000, bls. 53). Svipuð áhersla hefur verið á Kanaríeyjum. Rétt eins og rannsóknir hafa sýnt hvað varðar komu ferðalanga hér á Íslandi (Ingibjörg Sigurðardóttir 2016) hefur einnig á Kanarí verið áhersla á að dreifa ferðalöngum og skapa fjölbreytt atvinnutækifæri fyrir heimamenn (Scherrer o.fl, 2009). Eins og fyrr var sagt er pessi rannsókn hluti af stærra verkefnið sem byggir einnig á eigindlegum gögnum en söfnun eigindlegra gagna fyrir petta sama verkefni (p.e. fyrstu viðtöl á Kanarí við fólk innan ferðapjónustu sem og fræðilegar heimildir (Herrera o.fl., 2007, bls. 282) gefa til kynna að markaðsherferðir frá Spáni og Kanarí hafi pannig á síðustu áratugum lagt ríka áherslu á eyjarnar sem fjölbreyttan áfangastað sem hafi upp á margt að bjóða. Sú áhersla virðist ekki hafa áhrif á Islendinga sem velja Kanaríeyjar sem áfangastað, nema pá helst hjá yngsta og barnlausa ferðamannahópnum sem í 11\% tilfella tilgreindi áhugaverða menningu og samfélag sem ástæðu fyrir ferð peirra til eyjanna. Hér er áhugavert að velta fyrir sér atbeini ólíkra aðila í sköpun ákveðinna staða sem áfangastaða, p.á.m. pær áherslur sem Kanaríbúar hafa lagt upp með varðandi sköpun Kanaríeyja sem áfangastaðar, áherslur ferðaskrifstofa á Íslandi og einstaklinga sem fara í slíkar ferðir, sem og misvægi á milli pess sem íslenskir ferðamenn sækjast eftir og pess sem hefur verið lögð áhersla á alpjóðlega varðandi eyjarnar í markaðsetningu peirra á alpjóðlegum markaði. Eins og Vainikka (2013) bendir á er pó einföldun að ætla að upplifun allra sem sækja í fjöldaferðamennsku sé sú sama. Spurningakönnun, eins og hér er stuðst við, nær illa utan um óhefðbundnar leiðir sem ferðalangar nota til að stíga út fyrir kassa fjöldaferðmennsku (sjá til dæmis Larsen og Urry, 2011).

Peir svarendur sem höfðu ferðast til Kanaríeyja á árunum 2009-2019 endurspegla vel ólíkan fjölda til eyjanna tveggja, Gran Canaria og Tenerife, sem sjá má í greiningu á gögnum Hagstofu Spánar. Pannig höfðu 21\% svarenda farið í sinni síðustu ferð til Gran Canaria en 79\% til Tenerife. Peir sem ferðast til Gran Canaria gera pað einkum yfir kalda vetrarmánuði á Íslandi (febrúar og mars) en síður aðra mánuði ársins (nema júlí). Peir sem ferðast til Tenerife gera pað hins vegar jafnar yfir árið. Hér getur verið gagnvirkt samspil á milli framboðs og eftirspurnar á ferðum, par sem aðgengi að ákveðnum áfangastöðum, p.e. beint flug, getur veitt ákveðnum stöðum aukið aðdráttarafl (Eyrún Jenný Bjarnardóttir, 2010). Athyglisvert er að sjá að val á afpreyingu er mjög ápekkt á Gran Canaria og Tenerife, að undanskildu pví að fremur virðist sem ferðalangar til Tenerife dvelji á hóteli með fullu eða hálfu fæði (68\%) en peir sem ferðast til Gran Canaria (41\%). Aðrar rannsóknir á Norðurlöndum sýna að flestir sem ferðast til Kanaríeyja frá Norðurlöndunum - eða um 70\% - kaupa sérferð í gegnum norræna ferðaskrifstofu og hafa pakkaferðir með öllu inniföldu aukist mjög (Barros, 2014, bls. 5). ${ }^{4}$

Í pessari grein hefur eingöngu verið gerð tilraun til að kortleggja gróflega meginástæður fyrir vali á Kanaríeyjum sem áfangastað og helstu strauma frá Islandi til eyjanna, en augljóst er að dýpri skilnings er pörf á umfangi ferða pangað á ólíkum tímabilum par sem skoðað er m.a. nánar samspil framboðs og eftirspurnar á tíðni ferða, ferðavenjur Íslendinga í samanburði við aðra hópa, sem og pau efnahagsumsvif sem ferðamennska til eyjanna hefur falið í sér. Par parf að huga að pví að hópur Íslendinga býr á Kanaríeyjum og hann parf jafnframt að skoða betur í tengslum við hreyfanleika til og frá eyjunum pví eins og bent hefur verið á er oft erfitt að gera skýran greinamun á ferðamönnum og aðfluttu fólki (e. residental tourism) (O'Reilly, 2007).

\subsection{Niðurstöður}

Hérlendis hafa ferðalög Íslendinga erlendis verið lítið rannsökuð, par á meðal pættir eins og val ákveðinna áfangastaða, upplifun hópa á ákveðnum stöðum, sem og hvernig ferða- 
mennska leiðir af sér önnur efnahagsleg umsvif. Greinin er framlag til dýpri skilings á eðli hreyfanleika fólks til og frá Íslandi almennt sem oft hefur verið vanmetinn í fræðilegri umræðu (Kristín Loftsdóttir og Unnur Dís Skaptadóttir, 2019; Kjartan Sveinsson 2019). Ferðir til Kanaríeyja eru sérlega áhugaverðar í pessu tilliti vegna nokkurra ástæðna: Umfang peirra hefur farið vaxandi; hluti Íslendinga kýs að eyða sparnaði sínum par; pær skapa atvinnutækifæri fyrir aðra Íslendinga í margvíslegri ferðapjónustu og ferðirnar eru hluti af sögu fjöldaferðamennsku á Íslandi.

Í pessari grein voru fyrst og fremst skoðaðar ferðir frá Íslandi til Kanaríeyja og hvað Íslendingar gera á Kanarí. Fræðilegar rannsóknir hafa sýnt að ferðalög frá Norður-Evrópu til Suður-Evrópu eru ekki eingöngu vegna frís heldur eru samofin margskonar öðrum efnahagslegum gjörningum (Perles-Ribes o.fl., 2018; O’Reilly, 2007). Ferðamennska getur til dæmis byrjað sem frí sem síðar leiðir til kaupa á húsnæði og margskonar atvinnustarfsemi tengdri ferðamennsku, svo sem að vera leiðsögumaður eða standa fyrir fyrirækjarekstri par sem markhópur er samlandar (Parreño-Castellano og Domínguez-Mujica, 2016). Spurningakönnunin kom ekki sérstaklega inn á pennan pátt en í ljósi niðurstaðna fyrrnefndra rannsókna má áætla að hjá Íslendingum skarist einnig pessi ólíku markmið og að peir sem eru ferðalangar geti líka verið eða orðið húsnæðiseigendur eða leigusalar. Dagblaðagreinar og eigindleg gögn rannsóknarinnar gefa til kynna að slíkt eigi pannig einnig við um Íslendinga á Kanarí, en nánari greining á slíku er efni í aðra grein. Fræðifólk hefur jafnframt bent á að afmörkun milli ólíkra hreyfanlegra hópa er oft flæðandi og iðulega erfitt að aðgreina fyllilega milli peirra sem fara til Spánar sem ferðafólks, vegna vinnu eða til að setjast að tímabundið. Gögnin sem hér er unnið úr gefa vísbendingu um að hið sama eigi við um Íslendinga á Kanarí, en að ímynd landsins út frá sól og sandi ráði miklu í vali á Kanarí sem áfangastað, burtséð frá pví hver markmið ferðarinnar eru. Pó eru undantekningar par á eins og sjá má í atvinnurekstri tengdum fiskveiðum par sem Kanaríeyjar voru bækistöðvar fyrir veiðar í Vestur-Afríku. Pessi áhersla á strönd og sól hjá íslenskum ferðalöngum er jafnframt í nokkurri mótstöðu við pað sem stjórnvöld Spánar hafa verið að reyna að gera undanfarna áratugi í markaðssetningu landsins.

Að lokum má benda á breytt umhverfi árið 2020 hvað varðar tíð ferðalög, pá vegna aukinnar meðvitundar um skaðleg umhverfisáhrif peirra sem og gjörólíkar aðstæður til ferðalaga í samhengi við heimsfaraldur kórónaveiru. Ljóst er að slíkt gæti haft áhrif á áhuga og möguleika fólks í framtíðinni til að ferðast til staða eins og Kanaríeyja. Í pví ljósi má spyrja hvernig áframhaldandi próun hreyfanleika í heiminum muni mótast af pessum nýju hnattrænu aðstæðum.

\section{Aftanmálsgreinar}

1 Breska pundið veiktist mjög mikið í framhaldi af Brexit atkvæðagreiðslunni árið 2016, sem gæti skýrt auknar vinsældir svæðisins árið eftir.

2 Á hinum Norðurlöndunum voru árið 2019 flestar ferðir til Kanaríeyja á hverja 100 íbúa frá Noregi (8,2 ferðir) og næstflestar frá Danmörku (6,0), en fæstar frá Finnlandi $(4,8)$ og Svípjóð $(4,7)$.

3 Benda má á að olíuverð lækkaði einnig á tímabilinu sem skapar svigrúm fyrir ódýrari fargjöld.

4 Í grein Barros (2014) virðast Norðurlönd eingöngu vera Noregur, Danmörk, Finland og Svípjóð, p.e. Ísland er ekki talið með (bls. 4).

\section{Heimildir}

Almeida García, F. (2013). Tourism policy and territorial imbalances in Spain. Í: Szymańska, D. and Biegańska, J. (ritstj.), Bulletin of Geography. Socio-economic Series, No. 22, Toruń: Nicolaus Copernicus University Press, 7-19.

Andreu, L. J., Bigne, E. og Cooper, C. (2000). Projected and Perceived Image of Spain as a Tourist Destination for British Travellers. Journal of Travel \& Tourism Marketing, 9(4), 47-67. https://doi.org/10.1300/J073v09n04_03

Barros, C. P. (2014). The Nordic Tourists in the Atlantic Islands of Azores, Madeira and Canaries. Scandinavian Journal of Hospitality and Tourism, 13(1), 1-9.

Birkir Örn Gretarsson, Ingvar Porsteinsson og Oddný Póra Óladóttir. (2020). Ferðalög Íslendinga 2019 og ferðaáform peirra 2020. Reykavík: Ferðamálastofa. 
Cohen, S. A., Duncan, T. og Thulemark, M. (2015). Lifestyle Mobilities: The Crossroads of Travel, Leisure and Migration. Mobilities, 10(1), 155-172.

Domínguez-Mujica, J., González-Pérez, J. og Parreño-Castellano, J. (2011). Tourism and human mobility in Spanish Archipelagos. Annals of Tourism Research, 38(2), 586-606.

Eyrún Jenný Bjarnadóttir. (2010). Hlutverk flugvalla í próun áfangastaðar: Dæmi frá Norðurlandi. Í Ingjaldur Hannibalsson (ritstj.), Rannsóknir í Félagsvísindum XI: Viðskiptafræðideild (bls. 43-51). Reykjavík: Háskólaútgáfan.

Fargjöld til Kanarí undir kostnaðarverði. (2015, 4. desember). Mbl.is. https://www.mbl.is/vidskipti/frettir/2015/12/04/fargjold_til_kanari_undir_kostnadarverdi/

Fluttu til Tenerife og opna bar. (2016, 13. júlí). Mbl.is: Viðskipti, https://www.mbl.is/vidskipti/frettir/2016/07/13/ fluttu_til_tenerife_og_opna_bar/

Freysteinn Jóhannsson. (1995, 2. febrúar). Við stall meyjunnar í furutrénu. Morgunblaðið, 6-7.

Guðlaugur Bergmundsson. (1980, 1. ágúst). Íslensku sumar-pjóðflutningarnir til sólarlanda: Rúmlega 200 púsund á rúmlega 20 árum. Helgarpósturinn, 12-13.

Gunnar Pór Jóhannesson. (2012). Tími til að tengja? Af stefnumótun í ferðapjónustu á Íslandi. Stjórnmál E stjórnsýsla, 1(8), 173-193.

Gunnar Pór Jóhannesson og Huijbens, E. H. (2013). Tourism resolving crisis? Í D. Müller, L. Lundmark og R. Lemelin (ritstj.), New issues in polar tourism (bls. 133-147). Dordrecht: Springer.

Gustafson, P. (2002). Tourism and Seasonal Retirement Migration. Annals of Tourism Research, 29, 899-918

Hagstofa Íslands. (e.d.a). Gagnabanki. https://px.hagstofa.is/pxis/pxweb/is/Ibuar/Ibuar_mannfjoldi_1_yfirlit_Yfirlit_mannfjolda/MAN00000.px

Hagstofa Íslands (e.d.b). Gagnabanki: Landsframleiðsla og pjóðartekjur 1995-2019. https://px.hagstofa.is/pxis/pxweb/is/Efnahagur/Efnahagur_thjodhagsreikningar_landsframl_1_landsframleidsla/THJ01102.px

Haug B. G.M.S. Dann and M. Mehmetoglu. (2007). Little Norway in Spain: From Tourism to Migration, Annals of Tourism Resaerch, 34(1), 202-222.

Herrera, L. M. G., Smith, N. og Mejías Vera, M. Á. (2007). Gentrification, Displacement, and Tourism in Santa Cruz De Tenerife. Urban Geography, 28(3), 276-298.

Hjörtur Gíslason. (2007, 2 júní) Fjárfestingar upp á marga milljarða. Morgunblaðið, bls. 2.

Huijbens, E.H. og Gunnar Pór Jóhannesson. (2019). Tending to destinations: Conceptualising tourism's transformative capacities. Tourist Studies 19(3), 279-294.

Inda, J.X. og Rosaldo, R. (2008). Tracking global flows. Í J.X. Inda and R. Rosaldo (ritstj.), The anthropology of globalization: A reader (bls. 3-46). Oxford: Blackwell.

Ingibjörg Sigurðardóttir. (2016). Lífstíll verður ferðavara: Próun fyrirtækja í hestamennsku á Íslandi. Tímarit um viðskipti og efnahagsmál, 13 (2), 1-16.

ISTAC. (e.d.). Collection of air transport statistics: Monthly series of passenger entry Canary airports [1993- 2019]. ISTAC Instituto Canario de Estadística (ISTAC). http://www.gobiernodecanarias.org/istac/temas_estadisticos/sectorservicios/hosteleriayturismo/

Katrín Anna Lund, Kristín Loftsdóttir og Leonard, M. (2017). More than a stopover: Analysing the postcolonial image of Iceland as a gateway destination. Tourist Studies, 17(2), 144-163.

Kjartan Sveinsson. (2019). „Römm er sú taug:“ Íslenskir læknar á pverpjóðlegum atvinnumarkaði. Íslenska pjóðfélagið, 10(2), 63-79.

Kristín Loftsdóttir. (2015). The exotic north: Gender, nation branding and post-colonialism in Iceland. NORA-Nordic Journal of Feminist and Gender Research, 23(4), 246-260.

Kristín Loftsdóttir og Unnur Dís Skaptadóttir. (2016). Ísland í heiminum og heimurinn í Íslandi. Í Kristín Loftsdóttir, Unnur Dís Skaptadóttir og Anna Lísa Rúnarsdóttir (ritstj.), Ísland i heiminum, heimurinn í Íslandi (bls. 7-21). Reykjavík: Pjóðminjasafn Íslands.

Larsen, J., og Urry, J. (2011). Gazing and Performing. Environment and Planning D: Society and Space, 29(6), $1110-1125$

Nordic Statistics. (e.d.). Population 1 January by reporting country, age, sex and time. https://www.nordicstatistics. org/population-size/

Nýr áfangi á Kanarí blómaeyjan Tenerife [forsíðuauglýsing]. (1975, 24. desember). Tíminn: Jólapósturinn, 1.

Olsson, E., and K. O’Reilly. (2017. "North-Europeans in Spain: Practices of community in the context of migration, mobility and transnationalism." Nordic Journal of Migration Research, 7(3): 133-138.

O’Reilly, K. (2007). Emerging tourism futures: Residental tourism and its implications. Í C. Geoffroy og R. Sibley (ritstj.), Going Abroad: travel, Tourism and Migration. Cross-Cultural Perspectives on Mobility (bls. 144-157). Newcastle upon Tyne: Cambridge Scholars Publishing.

Parreño-Castellano, J. og Domínguez-Mujica, J. (2016). Working and retiring in sunny Spain: Lifestyle migration further explored. Hungarian Geographical Bulletin, 65(4), 407-420.

Perles-Ribes, J.F., Ramón-Rodríguez, A.B. og Such-Devesa, M.J. (2018). Second homes vs. residential tourism: A research gap. Tourism: An International Interdisciplinary Journal, 66(1), 104-107.

Rodriguez, V. (2001). Tourism as a recruiting post for retirement migration. Tourism Geographies, 3(1), 52-63.

Saarinen, J. (2004). 'Destinations in change' The transformation process of tourist destinations. Tourist studies, 4(2), 161-179. 
Samgönguráðuneytið. (1983). Ferðamál á Íslandi. Reykjavík: Samgönguráðuneytið.

Scherrer, P., Alonso, A. og Sheridan, L. 2009. Expanding the destination image: Wine tourism in the Canary Islands. International journal of tourism research, 11(5), 451-463.

Seðlabankinn, e.d. Greiðslumiðlun. https://www.sedlabanki.is/hagtolur/nanar/2020/10/14/Grei\%C3\%B0slu$\mathrm{mi} \% \mathrm{C} 3 \%$ B0lun/?stdID=21

Stefán Svavarsson. (2017). Frá saltfiski til sólarferða: Stjórnmála- og viðskiptatengsl Íslands og Spánar 1939-1959 [Óútgefin meistararitgerð]. Háskóli Íslands.

Svali liföi fyrstu tvö árin af á Tene (30.12. 2019). Mbl.is. https://www.mbl.is/smartland/frettir/2019/12/30/svali_ lifdi_fyrstu_tvo_arin_af_a_tene/

Spánarheimili veita alhliða pjónustu við íslenska fasteignakaupendur og -eigendur [kynning] (2021, 20. júlí). Fasteignakaup Erlendis, Fréttablaðið, 1-2.

Úr vetrarríki í sólarfrí í skammdeginu [auglýsing]. (1974, 13. október). Morgunblađið, 37.

Vainikka, V. (2013). Rethinking Mass Tourism. Tourist Studies, 13(3), 268-286.

WOW hefur flug til Gran Canaria. (2015, 5. nóvember). Mbl.is. https://www.mbl.is/vidskipti/frettir/2015/11/05/ wow_hefur_flug_til_gran_canaria/

Porsteinn Jónatansson. (1966, 2. september). Sumarið sótt heim um hávetur. Verkamaðurinn, 2. 